\title{
The Leafless Vanilla Species-Complex from the South-West Indian Ocean Region: A Taxonomic Puzzle and a Model for Orchid Evolution and Conservation Research
}

\author{
Cathucia F. Andriamihaja 1,2®, Aro V. Ramarosandratana ${ }^{2}{ }^{\mathbb{D}}$, Michel Grisoni ${ }^{3,4}$, \\ Vololoniaina Jeannoda ${ }^{2}$ and Pascale Besse ${ }^{1, * \text { (D) }}$ \\ 1 Université de La Réunion, UMR PVBMT, F-97410 St Pierre, La Réunion, France; \\ felambinintsoa.cathucia@univ-reunion.fr \\ 2 Department of Plant Biology and Ecology, University of Antananarivo, P.O. Box 906, \\ Antananarivo 101, Madagascar; arovonjy@gmail.com (A.V.R.); vololoniaina.jeannoda@gmail.com (V.J.) \\ 3 CIRAD, UMR PVBMT, F-97410 St Pierre, La Réunion, France; michel.grisoni@cirad.fr \\ 4 CTHT, BP11, Toamasina 501, Madagascar \\ * Correspondence: pascale.besse@univ-reunion.fr
}

Received: 14 October 2020; Accepted: 8 November 2020; Published: 24 November 2020

\begin{abstract}
The pantropical genus Vanilla is a member of the Orchidaceae family, one of the largest and most diverse families of angiosperms in the world. It originated in America and differentiated in America, Africa, and Asia. About 132 species of Vanilla have now been accepted since the discovery of the genus. Within the Vanilla genus, leaflessness has appeared at least three independent times, in Africa, Asia, and America as an adaptation to drought conditions. The South-West Indian Ocean (SWIO) region, a biodiversity hotspot for orchids, is home to seven leafless species. Chloroplast markers failed to differentiate species within this recent SWIO clade. Morphological traits used for description are very similar between species and do not provide reliable identification. Moreover, some of the species have overlapping flowering periods and geographic distribution in Madagascar, increasing the probability of finding some sympatric species and, therefore, hybrids. Leafless Vanilla species from the SWIO islands are thus an excellent model for understanding the evolution of orchids. For their conservation, and to confirm the identity of these leafless species, an integrated approach with classical taxonomy using a large number of samples, intense fieldwork on biology and ecology, and molecular studies using variable markers is necessary.
\end{abstract}

Keywords: Vanilla; leafless; South West Indian Ocean; diversification; taxonomy; biology; ecology; diversity; ethnobotany

\section{Introduction}

With more than 24,000 species and 700 genera worldwide, Orchidaceae is one of the largest families of flowering plants [1,2], and originated around 83 Mya (Million years ago) [3,4]. Orchids are widely celebrated for their beautiful flowers, extraordinary diversity, and potential medicinal proprieties. For example, among the 494 terrestrial and epiphytic orchid species recorded in Southern Africa, 49 are used as traditional medicinal plants to treat a wide range of diseases [5]. The South-West Indian Ocean (SWIO) islands are one of the global hotspots for orchids. The Orchidaceae family is represented by 65 genera and over 1000 species in this region [6]. Madagascar is the richest, with approximately 862 species, of which more than $85 \%$ are endemics [7], and 57 genera [8]. The Orchidaceae genus Vanilla can be considered as a flagship genus in the SWIO region, because the genus is represented 
there by wild, as well as cultivated, genetic resources. This region ranks first in terms of leafless Vanilla species richness [9,10]. It is also renown worldwide for its Vanilla fruit production, with the islands of Madagascar, Comoros and La Réunion being amongst the first world producers [11].

This paper provides an updated bibliographical review about the Vanilla genus. It is enriched by our own observations, and is focused on leafless species, particularly those indigenous and endemic to the SWIO islands (Madagascar, Comoros, Mayotte, Seychelles) and the East coast of Southern Africa. Some elements about the complexity of their taxonomy will be discussed.

\section{The Vanilla Genus and Leafless Species}

\subsection{Botany}

Vanilla plants are perennial vines characterized by thick and fleshy stems [12], a monopodial growth habit, aerial roots growing at each node, absence of pseudobulbs, fleshy fruits and wingless seeds [9]. The inflorescence is axillary [13]. The aerial roots are hairless, while the underground roots are hairy $[14,15]$. Leafless Vanilla species share most vegetative characteristics with leafy species, but they are photosynthetic plants with green, sometimes reddish to glaucous stems, distinguished by the absence of leaves or the modification of the leaves into scale-like structures $[10,16]$. Also, as opposed to leafy species, green stems of leafless species do not have a sclerenchyma band separating cortex from ground tissue [14]. Two types of roots were identified in leafless species from Madagascar: short, flattened or filiform roots used for attachment to a supporting tree, and long aerial roots up to $15 \mathrm{~m}$ exploring the soil for nutrition [15]. The same study demonstrated that populations in the north, where rainfall is higher, have thinner aerial roots with smaller xylem vessels than those in the arid south [15]. This is probably one of the developed strategy of succulent plants to face the scarcity or abundance of water in the soil [17]. Floral morphology is diverse but, in general, flowers are composed of three sepals, two petals, and a third large petal called labellum [10,12] forming a funnel surrounding the column [13]. Pollinia and stigma are separated by a membrane called the "rostellum". It usually prevents self-pollination within the same flower, although species are self-compatible $[18,19]$. The number of opened flowers per day varies from one to several, depending on the species. For Mexican leafy species, for example, it is generally one (e.g., V. phaeantha) to three (e.g., V. calyculata) [20]. In Madagascar, we observed that the number of opened flowers per inflorescence per day can go up to three in the leafless white-flower species ( $V$. madagascariensis, $V$. decaryana, V. bosseri), whereas this number is on average one flower and rarely two in the yellow-flower populations of Montagne des Français (V. humblotii). This is also the case of $V$. humblotii from Mayotte, for which on average 1.84 flowers open per day and per individual [21]. Flowers usually open in succession and are short lived (one day) (e.g., in leafless $V$. barbellata, V. claviculata, $V$. dilloniana [22]) but can remain for two or three days for some species like the leafy species $V$. inodora [20]. Unfertilized flowers rapidly fall, otherwise they turn into fruits in the form of an elongated capsule, called a "pod".

\subsection{Taxonomy}

The genus Vanilla Plum. ex Miller forms a monophyletic group (34.6 Mya) (Figure 1) in the large Orchidaceae family, the Vanilloidae sub-family, the Vanilleae tribe and the Vanillinae sub-tribe $[1,10,16,23]$. 


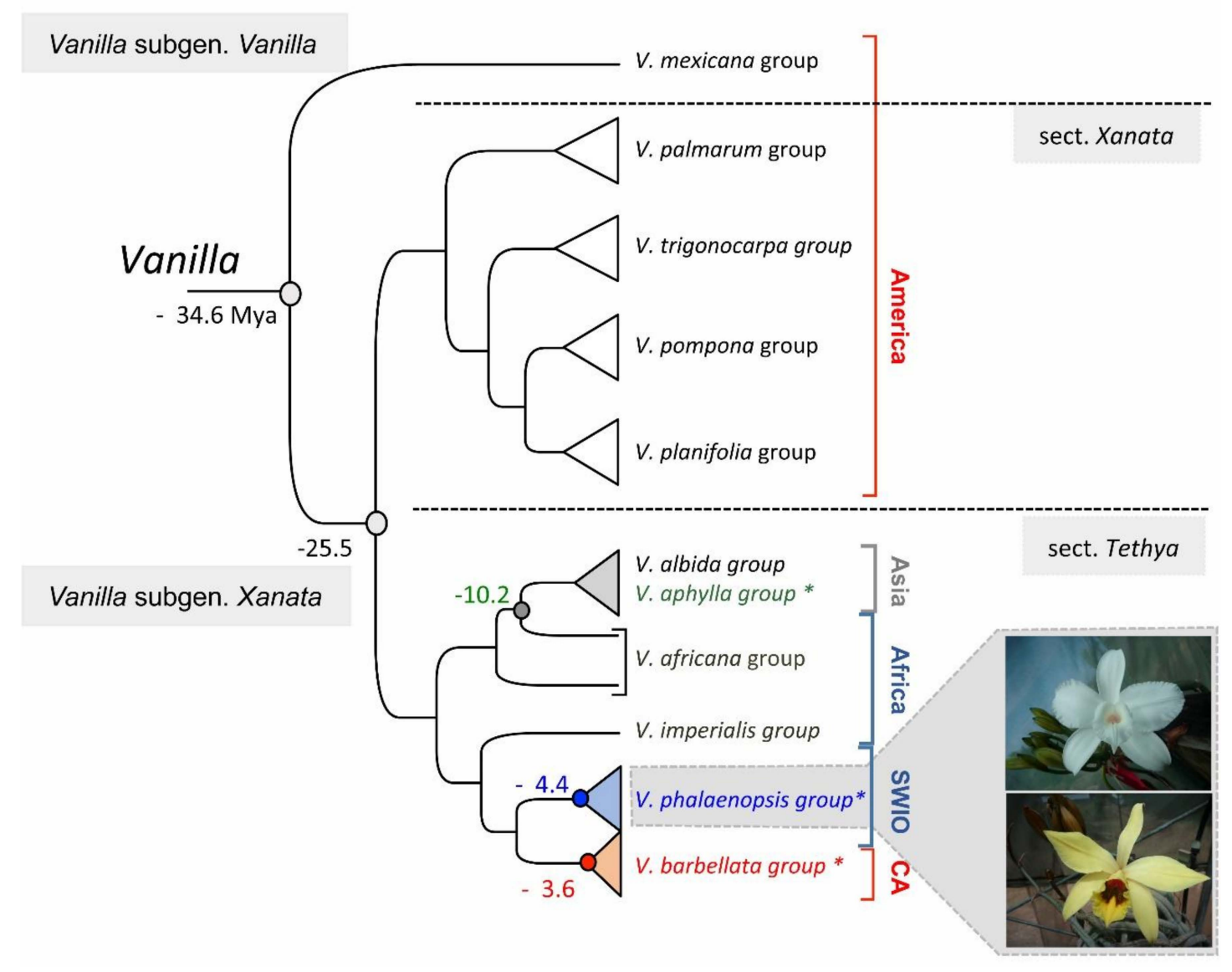

Figure 1. Representation of the ( $\mathrm{rbcL}, \mathrm{psaB}, \mathrm{psbB}, \mathrm{psbC}$ ) phylogeny of Bouetard et al. in 2010 including species groups defined by Soto Arenas and Cribb in 2010, showing leafless Vanilla species names in color (green for Asia, blue for SWIO, red for Caribbean CA) [3,9]. Node dates in Mya correspond to datations obtained by Bouetard et al., with the datation of Vanilla node at -34.6 Mya estimated using 71 Mya as the minimum age for Vanilloideae published by Ramírez et al., 2007, based on fossil evidence of an orchid pollinarium (of Meliorchis caribea) attached to an extinct stingless bee (Problebeia dominica) recovered in Miocene amber [3,4].

The first Vanilla subgeneric classification was essentially based on morphological descriptions and distinguished leafless species (Aphyllae section) with scale-like leaves, from leafy species (Foliosae section) which have conspicuous and persisting leaves $[10,23]$. The latter was divided into three sub-sections by Portères on the basis of labellum and leaf characteristics: Membranaceae, Papillosae, and Lamellosae $[10,16]$. Since the development of molecular approaches, which are playing an important role in plant taxonomy by allowing reliable phylogenetic-based classifications [24], phylogenetic markers (matK, rbcL, psaB, psbB, psbC, ITS) and chemical analyses have increasingly been used in Vanilla taxonomy $[3,9,16,20,25]$. A revision of the genus was done in 2010 by Soto Arenas and Cribb, who confirmed that Vanilla is monophyletic but noticed that the sections and subsections defined by Portères in 1954 are polyphyletic and incongruent with cladistic analysis [9]. Consequently, they proposed a new Vanilla classification based on phylogenetic and morphological reconstructions with two subgenera and 20 morphological groups [9]. The Vanilla subgenus is composed by species with membranaceous leaves, inflorescences poorly differentiated from the vegetative axis, a labellum without penicillar callus, a column united to the labellum only at the base, a sub-perpendicular anther and a concave stigma [9]. It is represented by V. mexicana, the type specimen for the Vanilla genus (Figure 1) [23].

The leafless species are now included in the other subgenus, Xanata, together with species with coriaceous to fleshy leaves [9]. Their inflorescences are well distinct from the vegetative axis, 
they have a column joined to the labellum at least on half of its length, and a parallel anther [9]. This second subgenus is further divided into two sections: the Xanata section comprising mostly the leafy neotropical species (American) and divided into six groups, and the Tethya section including the leafy and leafless paleotropical species (African and Asian) and Caribbean leafless species $[9,16]$. The same year, Bouetard et al. proposed a phylogeographic classification based on chloroplast DNA sequencing which was congruent with the revision by Soto Arenas and Cribb (Figure 1) [3,9]. It also showed that leaflessness is polyphyletic and has appeared at least three independent times, in Africa, Asia and America as a convergent adaptation to drought conditions following coastal establishments and island colonization [3]. The leafless species all belong to the subgenus Xanata section Tethya, except $V$. penicillata which is the only species included in section Xanata [9]. Also, this chloroplast phylogeny showed the surprising result that the Caribbean leafless species originated from an African ancestor, via transoceanic dispersion to America, rather than from an American leafy species [3]. This molecular data contradicts previous suggestions made by Portères in 1954, that leafless Vanilla species from the three geographical distributions (SWIO, Asia and Caribbean) originated from leafy species from neighboring continents [10].

\subsection{Evolution}

Vanilla is a transoceanic genus, found only in tropical forests between the 27th north and south parallels, but absent in Australia (Figure 2).

According to Rolfe, the diversification of the genus happened in Brazil and Guiana [23]. However, based on floral morphology, Portères suggested a primary diversification center in Indo-Malaysia that has evolved into two groups (Madagascar, Mascarene Islands, Africa versus Asia and Western Pacific islands), with the American species resulting from the migration of Asian species during the Tertiary (65.5-2.5 Mya) [10]. But the recent molecular phylogeny rejected this theory of Portères and suggested a South American center of diversity [3]. In 2005, Cameron stated that the differentiation of the genus Vanilla would have taken place before the dissolution of Gondwana [26], about 129 Mya [3]. However, following a fossil-based tree dating in Orchids [4], Bouetard et al. supported the alternative theory that Vanilla genus probably appeared 34 Mya (Figure 1), and its migration from the New World to the Old World occurred at the beginning of the Tertiary, about 25 Mya via a transoceanic dispersion, facilitated by the proximity of the continents and the presence of the series of islands of the mid-oceanic ridge of the Rio [3]. Three obvious cases of transoceanic migration events from Africa were also noted: (1) the dispersal of the genus from Africa to Asia; (2) from Africa to the SWIO islands and finally (3) from Africa to the Caribbean islands [3], the two last events concerning therefore the evolution of leafless groups in the SWIO and Caribbean islands. 


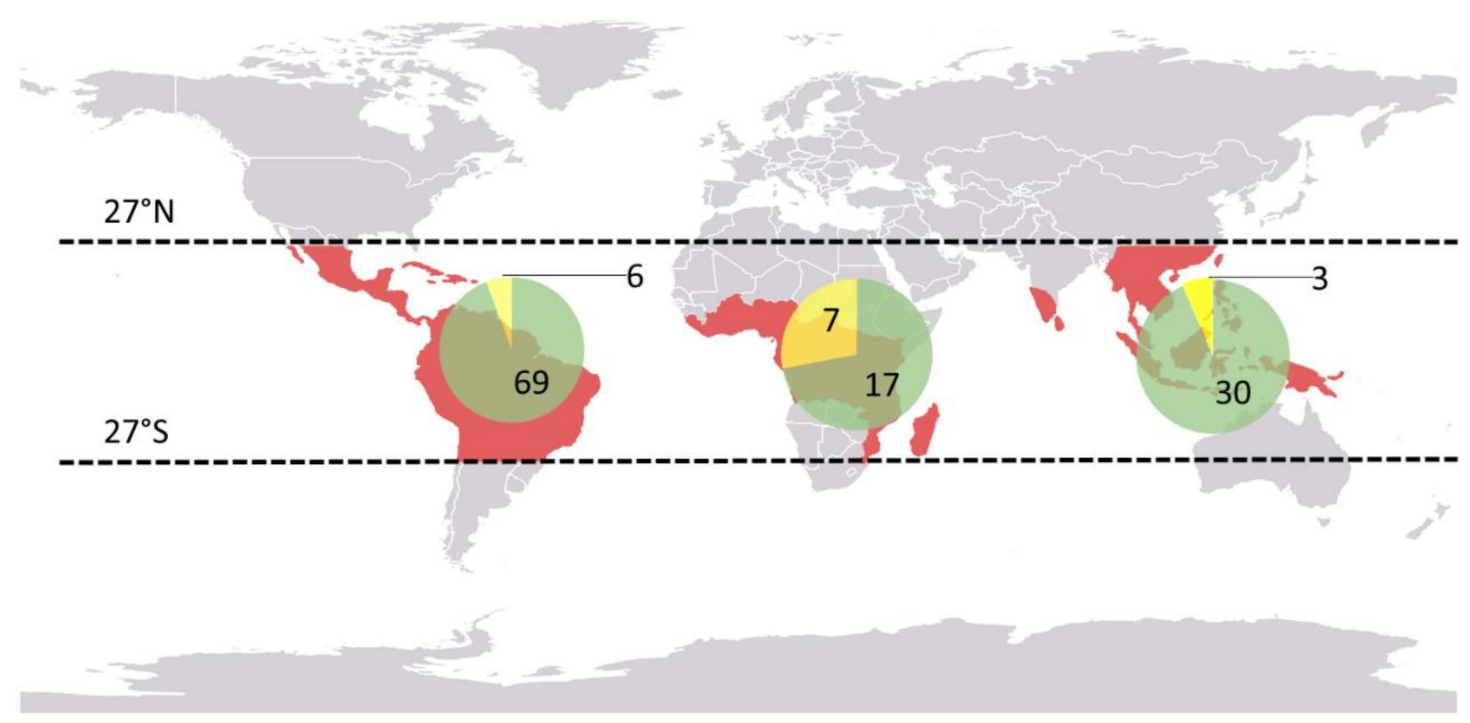

Figure 2. World distribution of Vanilla species: number of leafy Vanilla species (in green) and number of leafless species (in yellow) based on the World checklist of Selected Plant Families [27], the International Plant Name Index [28] and the database of Tropicos [29].

\subsection{Ecology}

Vanilla orchids are thermophilous [14]. These terrestrial, epiphytic or hemi-epiphytic plants are adapted to a variety of habitats [10,14,16,20], although they are scarce on mountain rain forest [14]. Lamellosae are found in fresh and wet places. They are mainly ombrophilous to mesophilous with various levels of heliophilia [10]. Papillosae species are also sciaphilous, living in rainforest formations, to heliophilous, sometimes growing in tropophilous and sub-xerophilous formations [10]. V. organensis, $V$. palmarum, $V$. wrightii and relatives without lamellae and with column fused to the labellum can be found in more mesophilic or even tropophilic formations in the area of Brazilian palm groves or wooded savannas [10]. Species with longitudinal lamellae and aromatic fruits are distributed in coastal or sublittoral forests [10]. However, some can be found in uncommon habitats like marshy forests (e.g., V. arcuata and V. paludosa [30]). While most species can climb to various substrates (trees and rocks), an epiphytic Vanilla (V. palmarum) is exclusively associated with nine species of palms in South America [31]. Some species can be found in different types of ecosystems like V. inornata [32]. There are species that thrive on particular substrates such as $V$. martinezii growing on an unual peat-like soil [20], V. planifolia alliance in Central America restricted to calcareous or sedimentary substrate [14] and $V$. insignis found on seasonally dry volcanic areas [14]. Vanilla species are often associated with mycorrhizal fungi $[15,16,33]$. For example, studies in Puerto Rico, Cuba and Costa Rica recorded several species belonging to three genera of mycorrhizal fungi (Ceratobasidium, Thanatephorus and Tulasnella) in V. potaei and V. planifolia [33].

Aphyllae is the only group that contains species adapted to hot, xeric, full sun habitats $[10,14,16]$. They grow on coastal bushes (e.g., V. roscheri and V. decaryana), in very dry tropophilous forests (e.g., V. madagascariensis), on sandy soils (e.g., V. perrieri, V. bosseri, V. aphylla), on rocks (e.g., V. humblotii, $V$. phalaenopsis and $V$. marmoreisense), on coral reefs ( $V$. roscheri) but also in mangrove swamps (e.g., V. barbellata and V. dilloniana) or in humid forests (V. madagascariensis) (Figure 3A,B) [8,10,34-36]. 

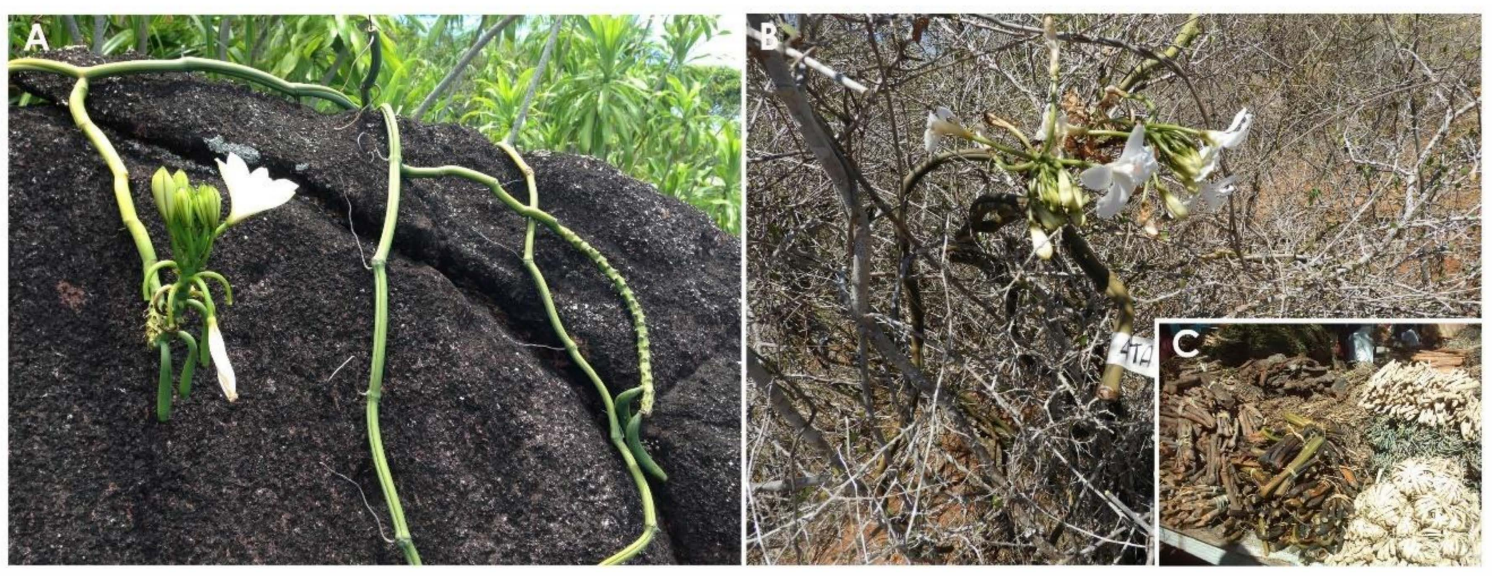

Figure 3. Ecology and usages of leafless Vanilla species: (A) V. phalaenopsis individual growing on a rock in Seychelles, (B) V. decaryana plant in thorny bushes in the south of Madagascar (Antandroka) and (C) leafless Vanilla stems for sale on the Tuléar market (Madagascar). (Photographies A, C: Pascale Besse, B: Cathucia F. Andriamihaja).

Leafless species are exclusively found on islands or on nearby littoral environment [10]. According to our observations in several populations in Madagascar, they are all hemi-epiphytes characterized by early germination and early stage in the soil, a root system exploring the ground and a long stem climbing along a support.

\subsection{Species Diversity and Distribution}

In the Vanilloideae sub-family, the Vanilla genus is the most species-rich [16]. However, the diversity of the Vanilla Plumier ex Miller genus is very complex. Indeed, as will be discussed later, Vanilla species delimitation is confused due to interspecific hybridization (e.g., $V$. barbellata $\times V$. claviculata [22]) and phenotypic plasticity $[18,37]$. Furthermore, numerous synonymies still exist between species (Table 1) $[9,10,27]$. This diversity is constantly in revision thanks to new discoveries. In the last decade, for example, 28 novel species have been described $[25,27,32,35,36,38-40]$. The first extensive classification of the genus carried out by Rolfe in 1896, listed 50 species with six aromatic species [23]. Portères, in 1954, reported 110 species (18 aromatic) [10], this was reduced to 90 species by Cameron and Chase in 1999 [41]. The number of valid species was extended to 106 (35 aromatic) in 2010 [9,14]. Altogether, 231 Vanilla species, subspecies, varieties and synonymies are listed in the International Plant Names Index website [28] and 240 are registered in the Tropicos website [29]. The current world checklist of selected plant families (WCSPF) records 230 Vanilla names, of which 130 are accepted [27].

By adding the species V. bosseri discovered by Allorge-Boiteau in 2013 [35] and the last described species $V$. armoriquensis [40] to the list of 130 accepted species in WCSPF [27], the present number of Vanilla species would rise to 132. Most of these species are endemic to tropical America (75) (including V. armoriquensis found in Peru in 2020), where the Amazon Basin constitute the center of diversity $[3,9,14], 24$ occur in Africa (including $V$. bosseri), and 33 are distributed in Asia, New Guinea and the Pacific islands (Figure 2). Based on Rolfe's sections 116 Vanilla species among these 132 are leafy, the remaining species being leafless.

After the discovery of the first leafless species in 1799 (V. claviculata), 18 species have been recorded by Portères in 1854 [10]. This number is reduced to 16 at the present time due to several synonymies (Table 1). Leafless species are mainly distributed on islands and nearby coastal regions: along the east African coast, SWIO islands, southeast Asia and Caribbean islands [9,10], except V. penicillata which is found in South America (Table 1) [9]. 
Table 1. List of the 16 leafless Vanilla species accepted by Govaerts et al. [27]. Synonyms are in brackets. $V$. bosseri was not present in the accepted list of Govaerts et al., but is listed as an accepted name in Tropicos [29]. Morphological species groups are according to Soto Arenas and Cribb [9].

\begin{tabular}{|c|c|c|c|c|}
\hline Species & Year & Continent & Group & Location \\
\hline V. aphylla Blume. (V. calopogon) & 1825 & Asia & V. aphylla & $\begin{array}{c}\text { Java, Malaysia, } \\
\text { Philippines, Thailand }\end{array}$ \\
\hline $\begin{array}{c}\text { V. barbellata Rchb.f. (V. articulata, V. bakeri, } \\
\text { V. parishii) }\end{array}$ & 1865 & America & V. barbellata & Caribbean Islands \\
\hline V. bosseri L. Allorge. (V. montagnacii) & 2013 & Africa & V. phalaenopsis & Madagascar \\
\hline V. claviculata Sw. & 1799 & America & V. barbellata & Caribbean Islands \\
\hline$V$. decaryana H. Perrier. & 1934 & Africa & V. phalaenopsis & Madagascar \\
\hline V. dilloniana Correll. & 1946 & America & V. barbellata & Caribbean Islands \\
\hline V. humblotii Rchb.f. & 1885 & Africa & V. phalaenopsis & $\begin{array}{l}\text { Comoros, Mayotte, } \\
\text { Madagascar }\end{array}$ \\
\hline V. madagascariensis Rolfe. & 1896 & Africa & V. phalaenopsis & Madagascar \\
\hline V. marmoreisense Soto Calvo. & 2019 & America & V. barbellata & Cuba \\
\hline V. penicillate Garay \& Dunst. & 1965 & America & $V$. penicillata & Colombia, Suriname, Brazil \\
\hline V. perrieri Schltr. & 1924 & Africa & V. phalaenopsis & Madagascar \\
\hline$V$. phalaenopsis Rchb.f. & 1867 & Africa & V. phalaenopsis & Seychelles \\
\hline V. poitaei Rchb.f. (V. correllii, V. eggersii) & 1876 & America & V. barbellata & Saint Domingue \\
\hline V. roscheri Rchb.f. & 1876 & Africa & V. phalaenopsis & $\begin{array}{c}\text { Tanzania, Kenya, } \\
\text { Mozambique, South Africa }\end{array}$ \\
\hline V. walkeriae Wight & 1845 & Asia & V. phalaenopsis & India, Sri Lanka \\
\hline V. wightii Lindl. (V. wightiana) & 1845 & Asia & V. aphylla & India, Sri Lanka \\
\hline
\end{tabular}

\subsection{Reproduction Biology}

In most cases, Vanilla species combine vegetative and sexual reproduction, except for $V$. mexicana, $V$. bicolor and $V$. palmarum for which artificial clonal propagation was reported to be unsuccessful or difficult $[18,37,42]$. The vegetative reproduction is possible as soon as an individual or a sufficient fragment of stem cutting can take root in the soil [37], sprout vegetative buds [42] and climb to a support to create a new individual. This clonal propagation constitutes the predominant reproductive, colonization and survival strategy. Studies on leafless species also revealed their ability for clonal reproduction in natural habitats. In Puerto Rico, Nielsen and Siegismund used polymorphic enzymes to analyse genetic diversity [22,43]. The results showed a high clonality rate for $V$. dilloniana (38\%) [22], a moderate rate for $V$. barbellata $(25 \%)$ [22] and a low rate for $V$. claviculata $(6 \%)$ [43]. In V. humblotii in Mayotte, microsatellite analyses showed a moderate clonality rate $(12.5 \%)$, with an average clonal patch size of $4.6( \pm 2.7) \mathrm{m}$, and a phalanx distribution [21].

The sexual reproduction, on the other hand, can occur only during the flowering period and only when the individual has attained maturity [20]. Also, it is common that some populations of a species fail to bloom for one or more successive years, as it was reported for V. hartii in tropical America [20]. There are, however, species that bloom throughout the year or during several months like V. inornata [32], $V$. rivasii [44] or $V$. bicolor [42]. Although some Vanilla species have an unusual high natural fruit set ( $>40 \%$ ) (Figure 4), which suggests self-pollination [20,42,45,46], most are pollinator-dependent due to the presence of the rostellum membrane separating the female and male parts of the flower $[10,19,21,23]$. Some mechanisms were reviewed by Gigant et al., to explain self-pollination: it may be caused by either stigmatic leak and/or the presence of a dehydrated or reduced rostellum, or agamospermy (e.g., V. bicolor and V. palmarum), but some spontaneous self-pollinations remain unexplained (e.g., V. planifolia and $V$. chamissonis) [18]. In addition to these mechanisms, Householder et al. also noted the absence of a rostellum in $V$. guianensis in Peru, facilitating pollen transfer between the two sexual organs [42].

Pollinators visit flowers for various reasons, such as collecting nectar, oil, pollen, stigmatic exudates or floral scents [47-49]. In Vanilla, floral odor seems to play an important role in attracting pollinators as in the case of $V$. trigonocarpa or $V$. pompona in America [14,20,42]. Other strategies are also used by orchid species to attract pollinators such as deceptive systems [50], as described for V. planifolia, 
$V$. odorata, and V. insignis in America [18]. In orchids, bee-pollination also requires a morphological association between floral characteristics and the insect traits [47,51-53].

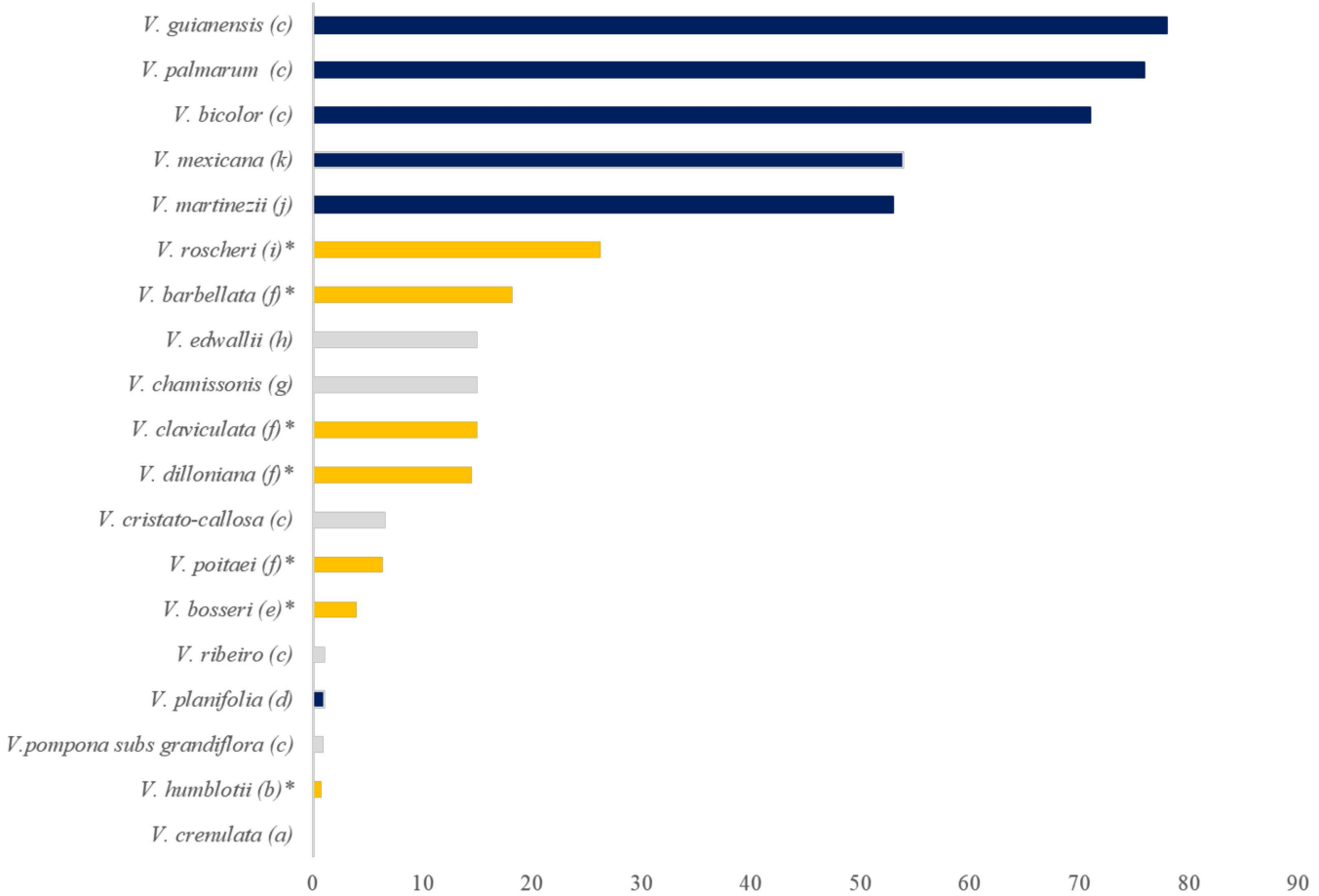

Figure 4. Rate of natural fruit set (\%) of Vanilla species according to (a) Soto Arenas and Cameron [14], (b) Gigant et al. [21], (c) Householder et al. [42], (d) Ackerman et al. [54], (e) Petersson [53], (f) Tremblay et al. [45], (g) Macedo [55], (h) Pansarin, Aguiar, and Pansarin, 2014, (i) Gigant et al., 2014, (j) Soto Arenas and Dressler, 2010, (k) Gigant et al. [46]. Species that can self-pollinate spontaneously are in dark blue, leafless Vanilla species are in orange and indicated by ${ }^{*}$, and the grey bars represent the other species.

In most cases in America, euglossine bee species were proved to be the main Vanilla pollinators (Table 2) [14,42,56], probably alongside with other species such as Trigona bees, Xylocopa bees [42], birds (e.g., V. abundiflora and V. griffithii [20]) and even bat species (e.g., V. insignis [20]).

With regards to the leafless Vanilla species, the low natural fruit set of six studied species $(<30 \%)$ testifies their dependence on pollinators (Figure 4). Soto Arenas and Cameron suggested that species in Puerto Rico would probably be pollinated by bees of the genus Centris, although it was also reported that they could be pollinated by euglossine bees [45]. In Africa, three leafless species have been studied for their reproduction biology, and the results show that they are most probably pollinated by female Xylocopinae (Allodapine) bees, although these bees might also act as pollen thieves $[19,21,53]$. Different Allodapine bee species were observed to move $V$. bosseri and $V$. roscheri pollen, but Meliponae and Anthophorine might be the true pollinators, respectively (Table 2). The presence of a rostellum that covers the entire stigmatic surface prevents self-pollination in V. roscheri [19]. Despite this, Sibaya populations (South Africa) have a high natural fruit set of up to $26.3 \%$ [19]. This can be explained by the large number of visiting insects recorded (about 11), of which three Apidae have been observed to move pollen probably for brood provisioning (Table 2) [19]. The observed natural fruit set of $V$. humblotii was very low $(0.62$ to $1.2 \%)$ in natural populations from Mayotte [21], possibly due to insufficient pollinators attributed to the highly fragmented landscape. Studies conducted on populations of $V$. bosseri in the CNRFEREF forest in Madagascar showed that this taxon is bee-pollinated, allogamous but self-compatible (like the two previous species) with a low flowering rate and a low natural fruit set of 3.96\% [53]. Although several bee species belonging to four orders (Hymenoptera, Lepidoptera, Orthoptera, Diptera) as well as one Primate species 
(Prophithecus verreauxi) were recorded visiting flowers [53], this low natural fruit set indicates a limited pollination. Indeed, only three bee species were found to carry pollen similar to the one of $V$. bosseri (Table 2) [53]. The author hypothesized that the pollinators may instead act as pollen thieves and reduce $V$. bosseri reproductive success [53].

Table 2. Potential pollinators of some Vanilla species. Leafless species are highlighted in bold.

\begin{tabular}{ccc}
\hline Vanilla Species & Potential Pollinators & References \\
\hline & America & {$[20]$} \\
V. insignis & Eulaema polychrome & {$[20]$} \\
V. planifolia & Euglossa spp. & {$[42,56]$} \\
V. pompona subs grandiflora & Eulaema spp. & {$[20]$} \\
V. cribbiana & Eulaema sp. & {$[57]$} \\
V. pompona & Eulaema cingulata & {$[20]$} \\
V. trigonocarpa & Euglossa asarophora & {$[52]$} \\
V. edwallii & Epicharis affinis & {$[58]$} \\
& Asia & {$[14]$} \\
V. siamensis & Thrinchostoma sp. & {$[53]$} \\
V.cf kaniensis & Aegilopa sp. & {$[19]$} \\
V. bosseri & Africa & {$[21]$} \\
V. roscheri & Macrogalea ellioti, Liotrigona mahafalya, Liotrigona madecassa \\
\hline
\end{tabular}

\subsection{Vanilla: A Taxonomic Complex Group}

Since 1703, when the first three species were described by Plumier, the taxonomy of the genus has always been considered to be difficult [23].

Indeed, the botanical identification of Vanilla species is mainly based on the description of flowers which are often ephemeral, variable within species due to phenotypic plasticity (e.g., V. barbellata, V. bakeri, V. parishii [10]), or similar between cryptic species [20,59]. Sometimes, no type specimen or botanical collections were recorded (e.g., V. guianensis [42]). Besides, the number of individuals used for species description was often limited due to scarcity of flowers [9]. Vegetative characteristics also show considerable intra-specific variations and inter-specific similarities between related species [34,35,37].

Hybridization is also one of the factors that can blur the boundaries between species, leading to a mismatch between morphology and genetics. Prezygotic and postzygotic barriers can generally prevent or limit hybridization [60]. In the Orchid family, prezygotic barriers include differences in floral morphology, and phenological and ecological isolation [51,57,61]. Postmating barriers result from incompatibility mechanisms, hybrid inviability or sterility, as reported for some deceptive orchids $[62,63]$. In the Vanilla genus, differences in flowering period and pollinator specificity are probably the two main factors that can limit gene exchange between sympatric species $[10,20,22,56]$. On the other hand, postmating barriers were not observed following artificial crossing experiments between closely related species (e.g., V. planifolia $\times V$. pompona [37]) or highly differentiated species (e.g., V. aphylla $\times$ V. planifolia $[59,64])$. Many Vanilla species occur in sympatry (Table 3), and cases of natural interspecific hybrids have been reported $[22,43,65]$. 
Table 3. Sympatric species recorded. Species for which hybridization was observed are highlighted in bold.

\begin{tabular}{|c|c|c|}
\hline Sympatric Species & Location & References \\
\hline \multicolumn{3}{|c|}{ Leafy Species } \\
\hline V. hartii \& V. cribbiana & Mexico & [20] \\
\hline$V$. hartii \& $V$. insignis & Mexico & [20] \\
\hline V. hartii \& V. odorata & Mexico & [20] \\
\hline$V$. hartii \& V. inodora & Mexico & [20] \\
\hline$V$. rivasii \& $V$. dressleri & Colombia & [44] \\
\hline$V$. javieri \& V. appendiculata & Colombia & [66] \\
\hline$V$. yanesha \& V. mexicana & Peru & {$[38]$} \\
\hline \multicolumn{3}{|c|}{ Leafless Species } \\
\hline V. barbellata \& V. claviculata & Puerto Rico & [43] \\
\hline$V$. barbellata \& $V$. dilloniana & Puerto Rico & [22] \\
\hline V. dilloniana \& $V$. claviculata & Puerto Rico & [22] \\
\hline V. madagascariensis \& V. perrieri & Madagascar & {$[8]^{1}$} \\
\hline V. madagascariensis \& $V$. bosseri & Madagascar & 1 \\
\hline
\end{tabular}

Thanks to an integrative taxonomic approach using ITS markers, the hybrid status of $V . \times$ tahitiensis, described as a new species in 1933, was recently proven [16,65]. It is a hybrid between $V$. planifolia and $V$. odorata, although it is still unclear where the hybridization took place. A study in Puerto Rico demonstrated the occurrence of hybrids between sympatric leafless species [22,43]. V. dilloniana, $V$. claviculata and V. barbelatta are three leafless species endemic to the Caribbean islands [22]. They share similar vegetative traits but can be easily discriminated from each other by their labellum $[9,10,22]$. The three species grow in sympatry in the western/southwestern part of the Susua Forest Reserve (Puerto Rico). Populations of the two species, V. barbellata and V. claviculata, presented the same alleles but differed in allelic frequencies [22,43]. Genetic differentiation within $V$. barbellata and $V$. claviculata species (mean $14.1 \%$ ) was low compared to the one between them $(23.7 \%)$, which allowed individuals to be correctly assigned to their respective species, except for one locality (Susua Reserve Forest) where both species co-exist [22]. Indeed, a complementary study demonstrated the existence of some hybrid individuals in this locality, with intermediate morphological characteristics between the two original taxa, and a high heterozygosity [43]. Furthermore, cross-pollination experiments were successful between $V$. barbellata and $V$. claviculata with high seed quality [43].

The mixed reproductive system (vegetative and sexual) of Vanilla can lead to a complex mixture of sexual reproduction and uniparental lineages [67]. Furthermore, polyploidization is frequent in Vanilla, especially in African species, increasing intraspecific diversity and making species delimitation even more difficult $[37,68,69]$. As a result of the three characteristics previously developed, i.e., (a) uniparental reproduction (clonal reproduction or self-fertilization), (b) interspecific hybridization between sympatric species, and (c) polyploidization capacity, the Vanilla genus gathers the criteria defined by Ennos, French, and Hollingsworth in 2005 to designate "Taxonomically Complex Groups" (TCGs) [67].

\subsection{Ethnobotanic and Commercial Importance}

The first use of Vanilla plants dates back to the time of the Maya civilization where it was called "sisbic" [20,70]. Vanilla was probably used by Mayas to treat skin wounds and bites at least since the 14th century, and the Mayas were also the first to develop the methods for treating fruits [70]. Then, other uses of Vanilla were also reported, such as vermicide in Mexico and Cuba, and to flavor rum by Chiapas at the beginning of the 19th century [20]. Roots of V. grandifolia and V. ovalis serve as a material for making fishing nets and baskets [14]. Vanilla species that produce aromatic fruits belong exclusively to the Vanilla subgenus Xanata sect. Xanata [9,71]. Three Vanilla species are cultivated and commercialized: $V$. planifolia worldwide especially in the SWIO region, $V . \times$ tahitiensis in the Pacific Ocean region and V. pompona in central America, the French Caribbean and Guiana $[14,68]$. 
But V. planifolia represents the most economically important species. It was first introduced in Europe in 1510 and used for medicinal and flavoring purposes [23]. The discovery of the manual pollination technique by Charles Morren in 1836 and the simplification of the technique in Reunion island by Edmond Albius in 1841 has made the culture of commercial Vanilla plants easy and possible worldwide [72].

Although only $V$. planifolia is of major economic interest on the global scale, the other species represent an important gene pool for the future breeding programs of commercial varieties. Indeed, other species have interesting traits that V. planifolia may not always have, such as high fruit set [42], self-pollination $[20,42,46]$, resistance to diseases $[59,64,73]$, medicinal proprieties $[10,23,70,74]$ and adaptation to drought $[10,23]$.

The leafless group comprises Vanilla species with a high potential for the future. In addition to their drought adaptation, they were shown to be resistant to Fusarium, one of the most destructive diseases of the $V$. planifolia plantations [75]. For example, four leafless Vanilla species from the SWIO region (V. phalaenopsis, $V$. humblotii, V. madagascariensis, $V$. roscheri) and $V$. aphylla from Asia were resistant or only slightly sensitive to Fusarium oxysporum f.sp. radices-vanillae after in vitro inoculation tests [59,64]. Also, leafless species are valued in a variety of traditional uses and for their medicinal properties. Chemical analyses realized on $V$. dilloniana stems showed antimicrobial and antiproliferative activities [74]. In India, local people use the stem of $V$. walkeriae as fodder for cows having new calves to increase their milking capacity [76] and to treat fever in cattle [77]. V. decaryana is used in the south of Madagascar for its aphrodisiac proprieties (Figure 3C) [10]. Traditional uses of leafless Vanilla plants are dominated by the knowledge of ethnic groups in southern Madagascar. Stems are used as a "tonic" for men but also in "post-partum" and child cares [78]. Ethnobotanical surveys have also revealed that the sister species $V$. madagascariensis is widely used in Malagasy cosmopolitan cities to treat certain diseases and for its aphrodisiac properties [79-81]. Also, V. roscheri serves as a charm to protect homes in South Africa [5].

Taking into consideration these interesting specificities, leafless species constitute an important genetic pool for Vanilla breeding programs especially in the present context of global climate change.

\subsection{Conservation Issues}

As for all wildlife species, wild Vanilla populations are in great danger due to anthropogenic activities. According to the IUCN red list, eight Vanilla species (V. hartii, V. inodora, V. insignis, $V$. odorata, $V$. phaeantha, V. planifolia, $V$. pompona, V. somai) are listed as endangered, and one species ( $V$. cribbiana) is categorized as critically endangered [82]. Some species have a very limited distribution (e.g., V. denshikoira in Colombia [39]) and are critically threatened by agricultural practices and deforestation (e.g., V. paulista and V. dietschiana in Brazil) [83-85]. Populations even consist, in extreme cases (e.g., V. javieri in Colombia), of a single known individual with a generally low fruit set [66]. In Malaysia, $V$. montana has been indicated as a rare species with the type specimen as the only known plant [9], and recently it has been reported to be a lost taxa [86]. Wild V. madagascariensis are also sometimes over-exploited to be used in traditional medicine [79].

Habitat destruction can also lead to the loss of genetic diversity or reduce the pollinator availability, which can impact the reproduction strategy of species. This was demonstrated for two leafless species from the SWIO: V. roscheri in South Africa and V. humblotii in Mayotte, respectively $[19,21,87]$.

A study using microsatellite markers demonstrated a total absence of genetic diversity, i.e., a generalized homozygosity and monomorphic loci in populations of $V$. roscheri near lake Sibaya in South Africa [19]. Two scenarios have been put forward to explain this worrying situation. First, habitat fragmentation could have led to population bottleneck and isolation, which resulted in inbreeding [19]. Alternatively, the Sibaya populations could be the result of clonal reproduction of a single migrant from Northern regions [19]. Although widely distributed, this species is considered as endangered and rare in several countries. For example, it has been classified as a flagship species, the second rarest endemic and threatened species in the St Lucia Wetland Park and an endangered 
species in South Africa [5,88]. V. roscheri is also one of the traditional African plants [5]. Given this lack of genetic diversity, anthropogenic pressures and potential uses, in situ and ex situ conservation efforts of $V$. roscheri in South Africa should be implemented urgently. Indeed, loss of genetic diversity is synonymous with an inability to evolve in response to environmental changes, and is often associated with inbreeding and reduction in reproductive fitness [89]. Thus, the current status of natural populations in other sites throughout the distribution range of $V$. roscheri should be monitored in order to prevent genetic erosion and preserve the species.

In Mayotte, V. humblotii is represented by nine populations spread over less than $20 \mathrm{~km}^{2}$ [87]. It is part of the protected species list cited in a Prefectoral decree (Arrêté $n^{\circ} 361 / D E A L / S E P R / 2018$ ), establishing the list of protected plant species and regulating the use of endangered plant species in the French department of Mayotte. According to the report carried out jointly by the IUCN (International Union for Conservation of Nature), the CBNM (Conservatoire Botanique National de Mascarin), the CBNF (Fédération des Conservatoires Botaniques Nationaux) and the MNHN (Muséum National d' Histoire Naturelle), V. humblotii is classified as "Vulnerable" in Mayotte due to competition with invasive species, clearing and burning carried out for banana, cassava and yam crops. A conservation strategy is being implemented [87]. A study using microsatellite markers revealed that, surprisingly, the genetic diversity of $V$. humblotii in Mayotte is relatively high. It is probably a remnant diversity, maintained almost exclusively by clonal reproduction [21], given the low fruiting rate and the lack of pollinators observed. Nevertheless, the very high anthropogenic pressure on $V$. humblotii populations in Mayotte could lead to a bottleneck, reducing genetic diversity, increasing inbreeding and putting populations in danger.

Given the lack of information or alarming status of some natural populations, the implementation of in situ and ex situ conservation actions is urgent for Vanilla species, as proposed by Flanagan and Mosquera-Espinosa for Vanilla species in Colombia [90].

\section{The Leafless Vanilla Clade from the SWIO Region: A Taxonomic Puzzle}

SWIO leafless Vanilla species are an interesting model for evolutionary studies of the genus Vanilla as they represent a recent monophyletic group [3,91] evolving in a mosaic of environments [92,93], with a high potentiality for breeding programs due to drought adaptation capacity $[10,23]$, disease resistance [64,73] and medicinal properties [10,79-81].

The SWIO islands are home for nine Vanilla species including two Malagasy leafy species belonging to the Papillosae sub-section of Portères and Tethya section of Soto Arenas and Cribb, and seven leafless species [8-10,34,35]. After describing the distribution and botanical differences between these leafless species, we will discuss the importance of this clade for evolutionary studies.

\subsection{Distribution}

Among the seven leafless species from the SWIO, V. humblotii is the only one that has been observed in several countries: Comoros, Mayotte and Madagascar [8,10,34], although it was described as endemic to the Comoros Archipelago (Figure 5) [10]. This species grows on rocks in the north of Madagascar and in the Comoros, whereas the closely related species V. perrieri is found in dry forests with sandy soils in the west and south of Madagascar (Figure 5) [8,10,34]. Three other species are indigenous to Madagascar, of which $V$. madagascariensis is the most widely distributed (Figure 5) $[8,10]$. Indeed, it occurs in the dry forests along the west coast and was also observed in the northeastern rainforests of Madagascar [8,29]. Given its large distribution, $V$. madagascariensis lives in sympatry with the other Malagasy leafless Vanilla species (Table 3, Figure 5) [8]. V. decaryana grows mainly in dry deciduous shrubs among Didieraceae in the south of Madagascar [10]. Finally, V. bosseri was observed in several localities in the west of Madagascar [35,53]. $V$. roscheri is found along the coast and islands of East Africa. The species has been observed mainly in Ethiopia, Somalia, Kenya, Tanzania, Zanzibar, Pemba Islands, Mozambique and South Africa $[5,9,10,19,94]$. V. phalaenopsis is described as endemic to Seychelles (Figure 5) $[9,10]$. 


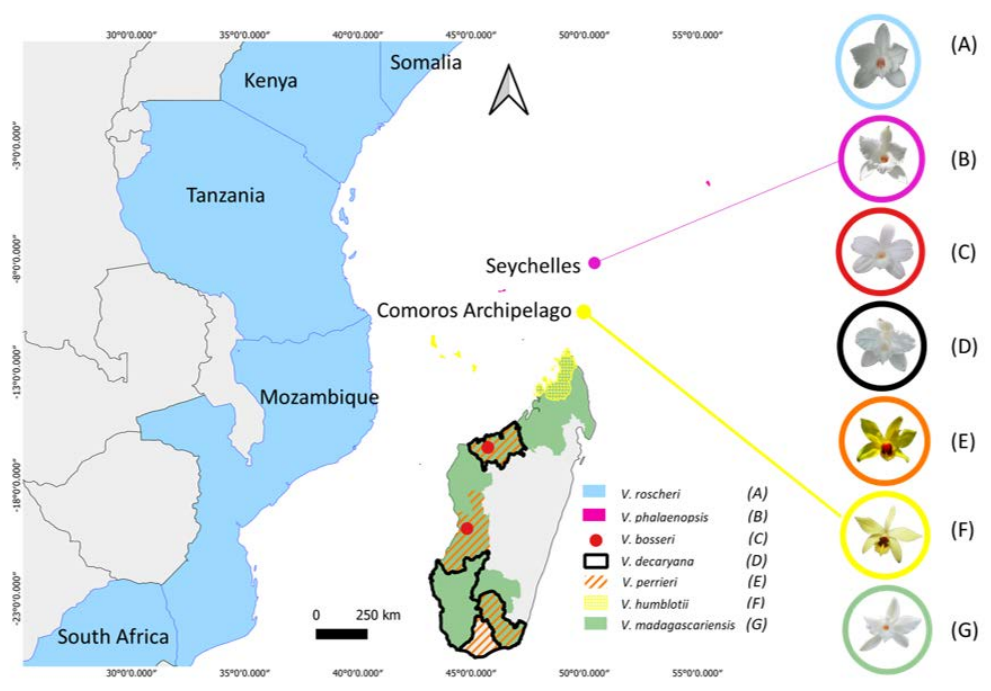

Figure 5. Distribution area of the seven leafless Vanilla species from the SWIO region according to Allorge-Boiteau [34], Allorge-Boiteau [35], Cribb and Hermans [8], Chinsamy, Finnie, and Van Staden [5], Luke [94], Portères [10]. Species are numbered from A to G. Images of their flowers are shown: photographies by (A) Rodolphe Gigant near Sibaya Lake (South Africa), (B) Thierry Pailler in Seychelles, (C) Cathucia F. Andriamihaja in Marosely (Madagascar), (D) Hoby Nomenjanahary in Mangily (Madagascar). (E) Cathucia F. Andriamihaja in Befandrama (Madagascar), (F) Johnson G. Andrianantenaina in Montagne des Français Park (Madagascar), and (G) Alemao Botomanga in Maromandia (Madagascar).

\subsection{Botanical Description}

Initially, Portères described seven leafless species in the SWIO [10], but one was invalidated by Soto Arenas and Cribb in 2010 in the absence of a Latin description and type specimen [9], and another one was recently added [35]. Seen for the first time in 2012 by Lucile Allorge-Boiteau in the Namoroka reserve [35], $V$. bosseri is one of the leafless species with white flowers endemic to Madagascar. Allorge-Boiteau describes it as a very fragrant species [35]. This species was also observed in the Morondava region by Bosser who identified it as V. montagnacii [35]. However, the latter was invalidated and Portère's description indicated the presence of a median hair in the basal position, which is not observed in $V$. bosseri $[10,35]$.

Six of the SWIO species form, together with $V$. walkeriae from Asia, the $V$. phalaenopsis morphological group according to Soto Arenas and Cribb's classification [9]. This group is characterized by a flabellate labellum with two rows of hairs beside the adaxial line, obtuse and very wide petals [9]. However, the last species discovered in this group, $V$. bosseri, was not included in the list. Although similar to the others, $V$. bosseri does not completely satisfy the description of the $V$. phalaenopsis group due to the absence of hairs on its labellum (Figure 6) [35]. 

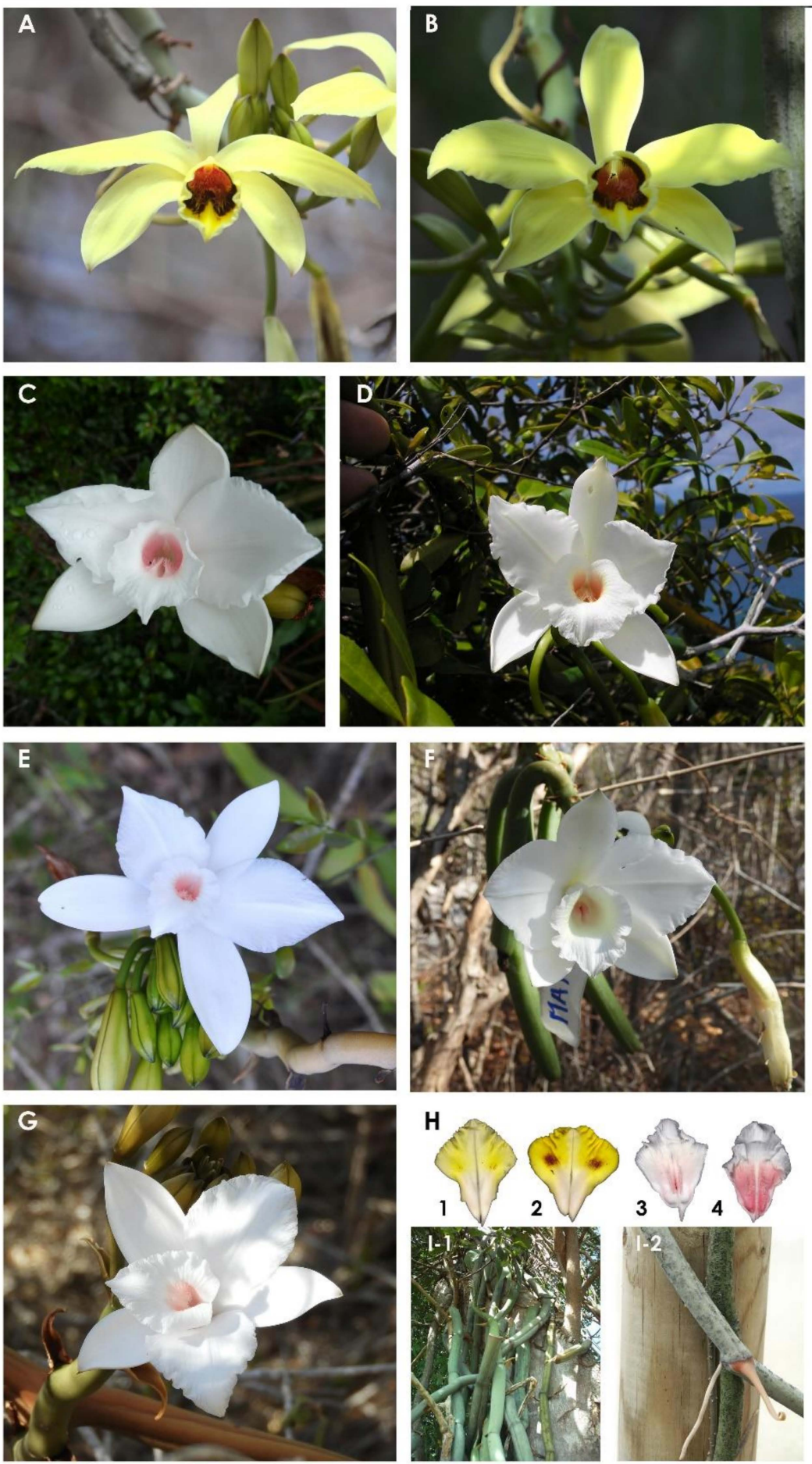

Figure 6. Morphological diversity of the seven leafless Vanilla species from the SWIO region. Flowers of (A): V. humblotii from Montagne des Français (Diego, Madagascar), (B): V. perrieri from Befandrama in the district of Analalava (Madagascar), (C): V. roscheri from Lake Sibaya in South Africa, (D): V. phalaenopsis from Seychelles, (E): V. madagascariensis from Maromandia in the district of Analalava (Madagascar), (F): V. bosseri from Marosely in the district of Port Bergé (Madagascar), (G): V. decaryana from Mangily in the district of Tuléar II (Madagascar). (H): scan of (1) the back side of $V$. humblotii labellum, (2) the back side of $V$. perrieri labellum, (3) the inside of $V$. bosseri labellum and (4) the inside of $V$. madagascariensis labellum. (I): Stems of (1) V. bosseri from Antsianitia (Madagascar), (2) V. humblotii CR0108 from the Comoros (BRC Vatel collection). (Photo A, B: Johnson G. Andrianantenaina, C: Rodolphe L. Gigant, D: Thierry Pailler, E: Alemao Botomanga, F,G,H: Cathucia F. Andriamihaja, I: Pascale Besse). 
Nevertheless, the seven leafless Vanilla species from the SWIO region are very similar morphologically $[9,10]$. Following our own comparative observations in the SWIO region, the main discriminant morphological features between the various species were identified. The major distinctive features between the seven species are presented in Table 4 and flower images are shown in Figure 6 .

Table 4. Leafless Vanilla species from the SWIO region: geographical distribution, flowering period and morphological characteristics of the flower and stem (C: color, LP: length of petal, LS: length of sepal, La: labellum, Fl: inflorescence, F: form, Tx: texture).

\begin{tabular}{|c|c|c|c|}
\hline Distribution & Flowering Period & Flower & Stem \\
\hline \multicolumn{4}{|c|}{ V. bosseri L. Allorge, 2013} \\
\hline & \multirow{4}{*}{ September-November ${ }^{b, c}$} & LS: $4.5 \mathrm{~cm}^{\text {a }}$ & \\
\hline $\begin{array}{l}\text { Madagascar: } \\
\text { Southwesten a }\end{array}$ & & C: white $^{\mathrm{a}}$ & C: grey in young stems and \\
\hline Namoroka ${ }^{\text {a }}$ & & La: pinkish throat with no & $\begin{array}{l}\text { turns green in old stems a } \\
\text { F: four longitudinal grooves a }\end{array}$ \\
\hline Morondava $^{\text {a }}$ & & pubescence and red protrusion & 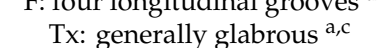 \\
\hline \multicolumn{4}{|c|}{ V. decaryana H. Perrier, 1934} \\
\hline Madagascar $\mathrm{d}$ : & \multirow{4}{*}{ January ${ }^{d}$} & LP: $3 \mathrm{~cm}^{\mathrm{d}}$ & \\
\hline South ${ }^{d}$ & & LS: $2.5 \mathrm{~cm}^{\mathrm{d}}$ & C: greenish-brown ${ }^{\mathrm{d}}$ \\
\hline Southwestern e & & Fl: $20-40$ flowers $^{\mathrm{d}}$ & F: two longitudinal grooves $\mathrm{e}$ \\
\hline Andohahela $\mathrm{e}$ & & La: pinkish throat with two & Tx: glabrous c,d,e \\
\hline \multicolumn{4}{|c|}{ V. humblotii Reichenbach f., 1885} \\
\hline & \multirow{7}{*}{ November-April g } & C: canary-yellow ${ }^{d, g}$ & \\
\hline $\begin{array}{l}\text { Comoros , Mayotte } \\
\text { Madagascar }{ }^{\mathrm{f}} \text { : }\end{array}$ & & LP: $5.5-7 \mathrm{~cm}^{\mathrm{d}}$ & \\
\hline $\begin{array}{l}\text { Madagascar }{ }^{1} \text { : } \\
\text { North }^{\mathrm{f}}\end{array}$ & & LS: $5.5-6.5 \mathrm{~cm}^{\mathrm{d}}$ & C: glaucous green ${ }^{\mathrm{d}}$ or bluish ${ }^{\mathrm{e}}$ \\
\hline Ankarana e & & La: very pubescent with velvety & F: one longitudinal groove $\mathrm{e}^{\mathrm{e}}$ \\
\hline Bemaraha e & & red or dark maroon throat $\mathrm{d}, \mathrm{h}$ & Tx: verrucose $e^{c, d, e}$ \\
\hline Andohahela e & & papillosae $^{\mathrm{h}}$ & \\
\hline \multicolumn{3}{|c|}{ V.madagascariensis Rolfe, 1896} & \\
\hline Madagascar ${ }^{\mathrm{d}}$ : & \multirow{5}{*}{ June-October ${ }^{\mathrm{a}, \mathrm{d}}$} & C: white $^{\mathrm{d}}$ & \\
\hline North (Sava, Diana, & & LP: $5.5-6.5 \mathrm{~cm}^{\mathrm{a}}$ & C: glaucous green ${ }^{\mathrm{d}}$ \\
\hline Ankarana) a & & LS: $5.5-6.5 \mathrm{~cm}^{\mathrm{d}}$ & F: one longitudinal grooves ${ }^{\mathrm{e}}$ \\
\hline Isalo $^{\mathrm{a}}$ & & Fl: $10-20$ flowers ${ }^{\mathrm{a}, \mathrm{d}}$ & Tx: glabrous $\mathrm{a}, \mathrm{d}, \mathrm{e}$ \\
\hline \multirow{2}{*}{\multicolumn{4}{|c|}{$\begin{array}{l}\text { La: pubescent with red throat }{ }^{\text {a }} \\
\text { V. perrieri Schlechter, } 1925\end{array}$}} \\
\hline & & & \\
\hline & \multirow{5}{*}{ November-December ${ }^{c}$} & C: sharp yellow $\mathrm{d}$ & \\
\hline Madagascar: & & LP: $5.5 \mathrm{~cm}^{\mathrm{d}}$ & C: dark green ${ }^{\mathrm{e}}$ \\
\hline Ankarafantsika ${ }^{\mathrm{d}}$ & & LS: $6.5 \mathrm{~cm}^{\mathrm{d}}$ & F: two longitudinal grooves ${ }^{\mathrm{e}}$ \\
\hline $\begin{array}{l}\text { Western coast (Majunga, } \\
\text { Morondava, Fort }\end{array}$ & & $\begin{array}{l}\text { La: pubescent with bright red or } \\
\text { dark brownish throat } \mathrm{d}, \mathrm{h} \text { not }\end{array}$ & $\begin{array}{l}\text { Tx: glabrous d,e, similar to } V \text {. } \\
\text { madagascariensis, but sometimes }\end{array}$ \\
\hline Dauphin, Ambovombe) ${ }^{\mathrm{e}}$ & & $\begin{array}{l}\text { papillosae } \mathrm{h} \text {, extension of the } \\
\text { hair on the back }{ }^{\mathrm{d}}\end{array}$ & verrucose $\mathrm{C}^{\mathrm{c}}$ \\
\hline \multicolumn{4}{|c|}{ V. phalaenopsis Reichenbach f., 1868} \\
\hline \multirow{4}{*}{ Seychelles ${ }^{\text {a }}$} & & C: white $^{\mathrm{d}}$ & \multirow{4}{*}{$\begin{array}{l}\text { C: green }{ }^{\mathrm{i}} \mathrm{F} \text { : one longitudinal } \\
\text { groove }{ }^{\mathrm{d}} \text { Tx: glabrous, similar to } \\
\text { V. madagascariensis }{ }^{\mathrm{i}}\end{array}$} \\
\hline & $\begin{array}{c}\text { April }^{\mathrm{i}} \\
\text { July-November }^{\mathrm{j}}\end{array}$ & $\begin{array}{l}\text { LP: } 5.5-6 \mathrm{~cm}^{\mathrm{d}} \\
\text { LS: } 5.5-6 \mathrm{~cm}^{\mathrm{d}} \\
\text { Fl: corymbiform }\end{array}$ & \\
\hline & & $\begin{array}{l}\text { La: two pubescent lines and } \\
\text { yellow-orange desk }{ }^{\mathrm{d}}\end{array}$ & \\
\hline & \multicolumn{2}{|c|}{ V. roscheri Reichenbach f., 1877} & \\
\hline East African: & \multirow{5}{*}{ November-March k } & C: white ${ }^{d}$ & \\
\hline Mozambique $^{\mathrm{d}}$ & & LP: $7.5-8 \mathrm{~cm}^{\mathrm{d}}$ & \\
\hline Zanzibar $^{\mathrm{d}}$ & & LS: $7.5-8 \mathrm{~cm}^{\mathrm{d}}$ & $\begin{array}{l}\text { C: reddish-brown } \\
\text { Tx: glabrous similar to }\end{array}$ \\
\hline $\begin{array}{l}\text { Pemba Island }{ }^{\mathrm{d}} \\
\text { Dar-es-Salam }_{\mathrm{d}}\end{array}$ & & Bud: brownish ${ }^{\mathrm{d}}$ & V. madagascariensis ${ }^{\mathrm{i}}$ \\
\hline $\begin{array}{l}\text { Dar-es-Salam }{ }^{\mathrm{a}} \\
\text { South Africa }{ }^{\mathrm{k}}\end{array}$ & & $\begin{array}{l}\text { La: two pubescent lines desk } \\
\text { and pink throat } \mathrm{d}, \mathrm{k}\end{array}$ & \\
\hline
\end{tabular}

The stem texture and color are often different between species, with species showing glabrous or verrucose; grey, brown, red to green stems; with one to four longitudinal grooves $[10,19,21,34,53]$. But these characters are also highly variable within species. Based on flower color, species can be divided into two groups: species with yellow flowers and those with white flowers $[8,10,34]$. $V$. humblotii and V. perrieri compose the first group. The former has a verrucose stem and yellow canary 
flowers, that allows to distinguish it from $V$. perrieri which exhibits a glabrous stem and sharp yellow flowers $[10,34]$. One of the particularities of $V$. perrieri is also the presence of an extension of the hairs outside the hulls on the back of the labellum (Figure 6) [10]. Five closely-related species compose the white-flower group, of which three are endemic to Madagascar [8-10,34,35]. All have a smooth stem and hairs on the inside of the labellum, except $V$. bosseri whose labellum is rather characterized by two pink crests and a short red protrusion between the crests (Figure 6) $[34,35,53]$. The five species also differ in the color of the inside of the labellum and flower size, $V$. decaryana being the one with the smallest flowers (Table 4) $[9,10,34]$.

\subsection{A Taxonomic Puzzle}

When genetic differentiation is associated with consequent morphological differentiation, species delimitation is generally easy [95]. But in some cases, when species are highly differentiated morphologically but little divergent genetically (adaptive radiation), or when the morphological change is slow and does not reflect genetic divergence (nonadaptive radiation), species delimitation becomes a challenging task [95]. Often, adaptive radiation occurs among a related and recently diverged sympatric group [95-98], whereas nonadaptive radiation would be the result of prolonged geographical isolation of several populations of the same species, followed by subsequent slow speciation resulting from nonecological processes [98]. However, nonadaptive radiation can be followed by adaptive radiation when the environment of the two species becomes different [98]. Species delimitation is even harder when recent sympatric species can hybridize $[97,99]$. SWOI leafless Vanilla species are one of the most recently formed groups in the genus Vanilla (4.4 Mya) (Figure 1) [3]. Therefore, species divergence within the group has occurred recently. The observations we made on the vegetative and floral organs of individuals belonging to three species $V$. roscheri, $V$. phalaenopsis and $V$. madagascariensis present in the BRC (Biological resources center) Vatel (Reunion island) allowed us to confirm that they are closely related and difficult to differentiate. Flowers mainly show variations in size (Table 4), which is not always a sufficient criterion to discriminate species, especially in the Vanilla genus with high intra-specific variation [100]. Also, Cameron suggested that these three species could probably be morphological variations of a single species [101]. Given that these three species are supposedly endemic to three different geographical areas (East Africa, Madagascar, Seychelles), whose separation took place well beyond the formation of the leafless group (Figure 7), we suppose that they are probably separate populations of the same species that have recently diverged and are evolving via nonadaptive radiation.

On the other hand, the five described leafless species found in Madagascar can be differentiated by the size of the flower, and the color and the form of the labellum $[8,34,35]$. As previously discussed, these species are sympatric in several areas, and interspecific hybridization is possible between Vanilla species $[18,43]$. During our fieldwork in the north of Madagascar, we observed one individual with flowers showing intermediate colors between yellow and white, suggesting a possible hybridization between species. Unfortunately, we were unable to obtain images. The possible occurrence of five leafless species in Madagascar with some overlapping distribution and the possible hybridization raise numerous questions about the mechanisms of their evolution and speciation. For these Malagasy species, adaptive radiation and ecological speciation have probably occurred in the past via one of the five mechanisms reported in Madagascar by Vences et al. [92]. Concerning the remaining species, $V$. humblotii, supposed to be endemic from the Comoros archipelago, its presence in Madagascar and its great morphological similarity with the native Malagasy species, V. perrieri, suggest that they either form subspecies of the same species or are the result of colonization followed by differentiation long after the formation of the islands. Species movement between SWIO islands has already been demonstrated in various genera including birds (e.g., Nectarinia, Hypsipetes [102,103]), plants (e.g., genus of Coffeeae tribe [104]) and more especially orchids (e.g., Bulbophyllum, Angraecum [105-107]). 


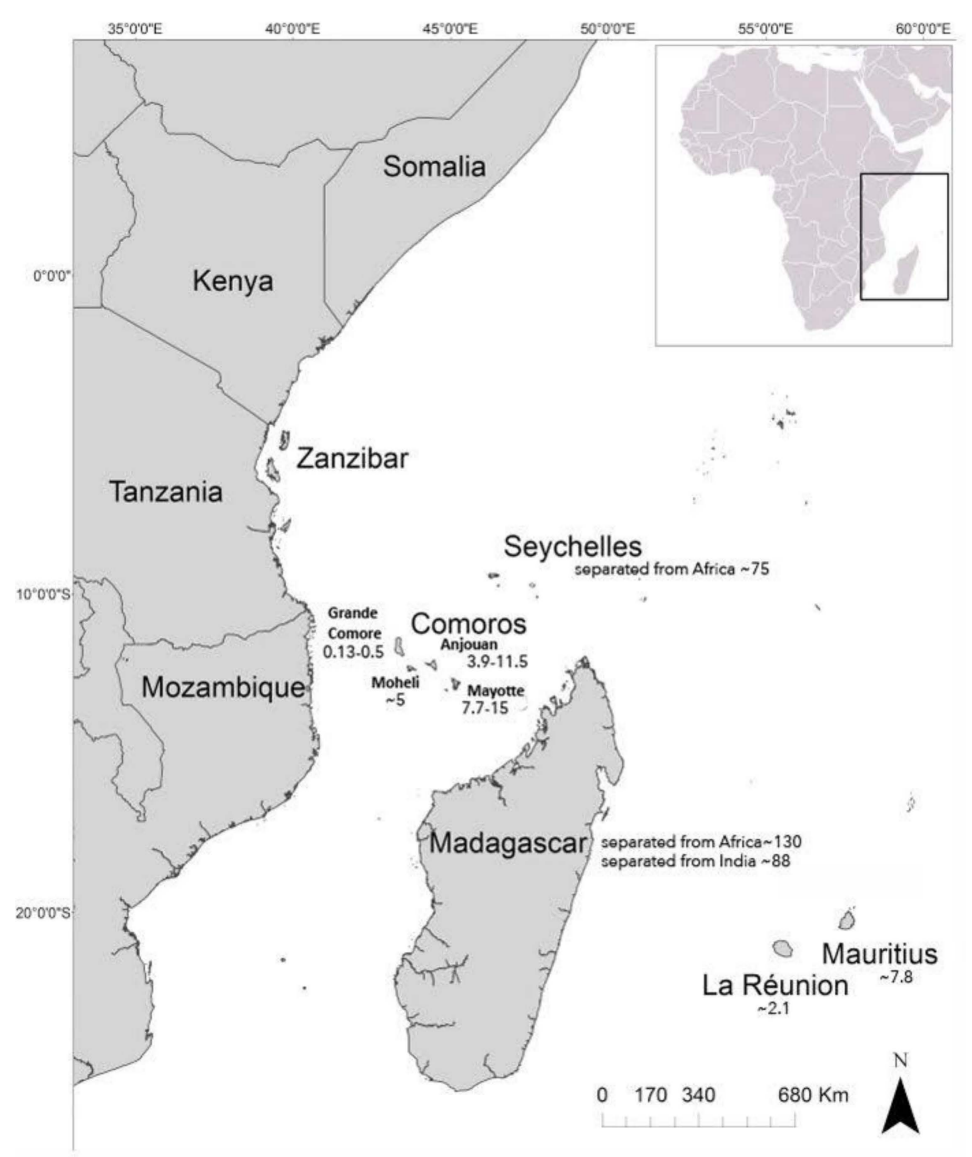

Figure 7. Map showing the date (in Mya) of separation and formation of the SWOI islands adapted from Warren et al., 2003 [102].

Complexes of closely related species endemic to different islands provide an interesting model to better understand the different stages of speciation. In fact, islands own several characteristics that make them an excellent natural laboratory, including the presence of strict boundaries, the isolation, the high endemicity, the small size relative to continent, the geographic history, and the environment heterogeneity providing natural ecological and evolutionary replicates [108]. This interest in islands goes back to Darwin, who used a variety of islands as a model to illustrate different patterns of species richness and evolution, of which the famous Galapagos islands largely studied until now [109]. All these interesting features are visible in the SWIO islands, which are a biodiversity hotspot [110]. At the scale of Madagascar, the oldest island of the SWIO region separated from Africa 130 Mya and from India 88 Mya (Figure 7), seven bioclimatic regions with unique vegetation are present, ranging from a humid tropical forest in the east to an arid biome in the far south (Figure 8) [93]. This Malagasy ecological contrast is the source of various speciations, particularly in the animal kingdom (e.g., lemur species [111,112]). 


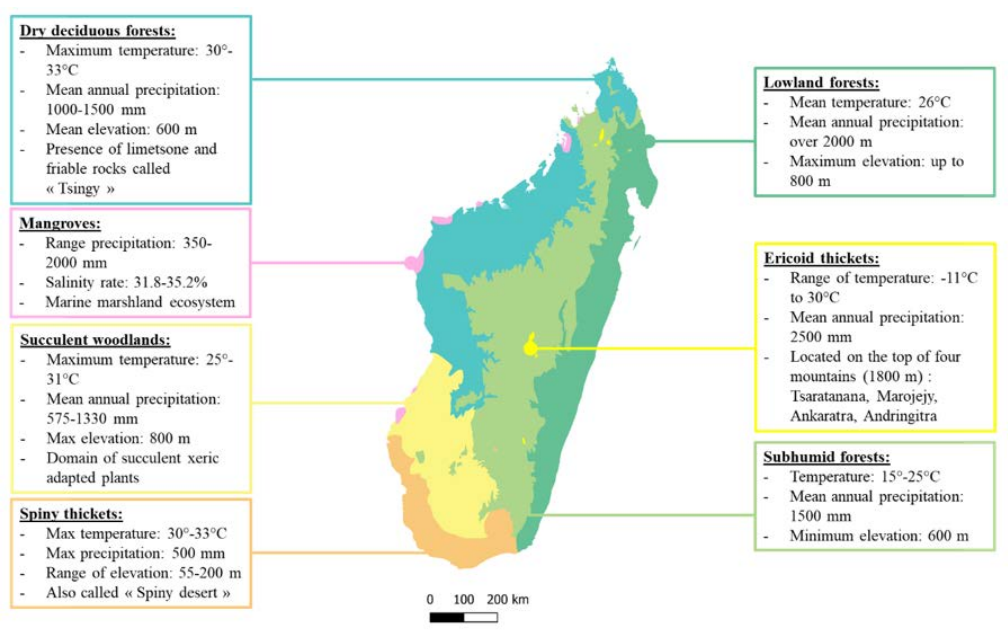

Figure 8. Map of the seven ecoregions of Madagascar adapted from WWF's ecoregion in Burgess et al. [93].

Moreover, SWIO islands have variable ages and different geographical histories (volcanic islands like Comoros vs. mainland islands such as Madagascar and Seychelles), allowing to test several speciation mechanism hypotheses. The presence of Vanilla sister-species, endemic to the African continent or to different islands ( $V$. roscheri, $V$. madagascariensis, $V$. phalaenopsis) and the presence of sympatric Vanilla species in Madagascar offer a promising system for species diversification studies.

\subsection{Conclusion and Prospects}

Because of today's environmental crisis, biodiversity conservation has become a major global concern. Two kinds of strategies are generally recommended to achieve this goal: species-based conservation and conservation at the ecosystem scale [113]. Whatever the approach, efforts to catalogue and understand biodiversity form the basis for species and habitat effective conservation. However, correctly defining species belonging to taxonomically complex groups like Vanilla, where conventional classification fails, is not always evident. Yet, incorrect taxonomic classification could have important consequences for basic biological research and harm biodiversity conservation [114,115]. For example, V. humblotii is considered as endemic to the Comoros archipelago and is classified as endangered (EN) in Mayotte and therefore under protection status since 2006. However, this species has also been described as present in Madagascar, making its overall conservation status questionable. According to many authors, taxonomy often requires the comparison between several models based on different types of data and should incorporate molecular investigations [114,116,117]. In the case of the seven leafless Vanilla species native to the SWIO, classifications based on morphological characters in a very detailed manner $[10,34,35]$, on a large sampling, as well as population genetics and phylogenetic analyses are needed. Chloroplast genes $\mathrm{rbcL}, \mathrm{psaB}, \mathrm{psbB}$, and $\mathrm{psbC}$ have already been used for Vanilla phylogeny [3]. But these sequences are not variable enough to properly clarify the taxonomy in the recent SWIO clade [24,118]. As the available information on genetic structuring and phylogeny of these species is insufficient, the resolution of their taxonomy is problematic, which limits the development of conservation actions. Integrative taxonomy using phylogenetic analyses with more divergent regions of DNA such as ITS [24,118], genetic structuring analysis with highly polymorphic and rapidly evolving markers like microsatellites [97], completed by a morphological comparison of several individuals from the different species like what has been done for Carappa spp. [116] and Coffea spp. [119] will be a powerful approach to clarify their taxonomy. Such integrative approaches are currently becoming frequent in species delimitation $[9,20,25,99,116]$ and mandatory for species complexes $[97,99,116]$ or cryptic species $[114,120,121]$. These different markers associated with other environmental variables such as climatic or soil data would also help to understand the speciation processes at play [122-124]. 
Issues related to interspecific hybridization should also be addressed in taxonomic and phylogenetic studies [99] of these seven SWIO leafless species.

In addition, interspecific and intraspecific crossbreeding tests as done for $V$. barbellata and V. claviculata [43], V. bosseri [53], V. humblotii [21] and V. roscheri [19], the modeling of the geographical distribution and population genetic studies of the different species will greatly improve our knowledge about these interesting models and allow the implementation of effective and sustainable conservation programs.

Author Contributions: Conceptualization, P.B. and C.F.A.; investigation, C.F.A.; writing-original draft preparation, C.F.A.; writing-review and editing, P.B., A.V.R., M.G. and V.J.; supervision, P.B., A.V.R., M.G. and V.J.; project administration, P.B. All authors have read and agreed to the published version of the manuscript.

Funding: This work was funded by the European Regional Development Fund attributed by the Regional Council of La Réunion, grant number TIERS 263105. It was also supported by the University of Antananarivo, the University of La Réunion and the CIRAD.

Acknowledgments: We thank Thierry Pailler, Johnson Gabriel Andrianantenaina, Hoby Nomenjanahary, Alemao Botomanga and Rodolphe Gigant for photographs.

Conflicts of Interest: The authors declare there is no conflict of interest.

\section{References}

1. Chase, M.W.; Cameron, K.M.; Freudenstein, J.V.; Pridgeon, A.M.; Salazar, G.; van den Berg, C.; Schuiteman, A. An updated classification of Orchidaceae. Bot. J. Linn. Soc. 2015, 177, 151-174. [CrossRef]

2. Fay, M.F.; Chase, M.W. Orchid biology: From Linnaeus via Darwin to the 21st century. Ann. Bot. 2009, 104, 359-364. [CrossRef] [PubMed]

3. Bouetard, A.; Lefeuvre, P.; Gigant, R.L.; Bory, S.; Pignal, M.; Besse, P.; Grisoni, M. Evidence of transoceanic dispersion of the genus Vanilla based on plastid DNA phylogenetic analysis. Mol. Phylogenetics Evol. 2010, 55, 621-630. [CrossRef] [PubMed]

4. Ramírez, S.R.; Gravendeel, B.; Singer, R.B.; Marshall, C.R.; Pierce, N.E. Dating the origin of the Orchidaceae from a fossil orchid with its pollinator. Nature 2007, 448, 1042-1045. [CrossRef] [PubMed]

5. Chinsamy, M.; Finnie, J.F.; Van Staden, J. The ethnobotany of South African medicinal orchids. S. Afr. J. Bot. 2011, 77, 2-9. [CrossRef]

6. Pailler, T.; Andilyat, M.; Andrianarivo, C.; Baider, C.; Bytebier, B.; Filer, D.; Henze, F.; Morel, C. Guide des Orchidées des Îles de l'Océan Indien: Espèces Indigènes et Endémiques, 1st ed.; Commission de l'Océan Indien: La Réunion, France, 2018; pp. 8-163.

7. Callmander, M.W.; Phillipson, P.B.; Schatz, G.E.; Andriambololonera, S.; Rabarimanarivo, M.; Rakotonirina, N.; Raharimampionona, J.; Chatelain, C.; Gautier, L.; Lowry, P.P. The endemic and non-endemic vascular flora of Madagascar updated. Plant Ecol. Evol. 2011, 144, 121-125. [CrossRef]

8. Cribb, P.; Hermans, J. Field Guide to the Orchids of Madagascar; Royal Botanical Gardens: Kew, UK, 2009; ISBN 978-1-84246-158-7.

9. Soto Arenas, M.Á.; Cribb, P. A new infrageneric classification and synopsis of the genus Vanilla Plum. Ex Mill. (Orchidaceae: Vanillinae). Lankesteriana 2010, 9, 355-398. [CrossRef]

10. Portères, R. Le Genre Vanilla et ses Espèces. In Le Vanillier et la Vanille dans le Monde; Bouriquet, G., Ed.; Editions P. Lechevalier: Paris, France, 1954; pp. 94-920.

11. De La Cruz Medina, J.; Rodriguez Jiménes, G.C.; Garcia, H.S.; Zarrabal, T.L.R.; Alvarado, M.A.G.; José, V. Vanilla: Post-Harvest Operations; Food and Agriculture Organization of United Nations: Veracruz, Mexico, 2009; pp. 1-25.

12. Bosser, J.; Lecoufle, M. Les Orchidées de Madagascar; Parthénope; Biotope: Mèze, France, 2011; ISBN 2-36662-047-0.

13. Descouvrières, P. Encyclopédie Des Orchidées Tropicales-1200 Espèces, Plus De 1000 Photographies|Rakuten; Ulmer: Paris, France, 2011; Volume 1, ISBN 978-2-84138-472-3.

14. Soto Arenas, M.A.; Cameron, K.M. Vanilla. In Genera Orchidacearum: Orchidoideae; Pridgeon, A.M., Cribb, P., Chase, M.W., Rasmussen, F.N., Eds.; Oxford University Press: Oxford, UK, 2003; pp. 321-334. 
15. Botomanga, A. Stratégies D'adaptation à la Sècheresse et à la Dégradation de L'habitat des Racines de Vanilliers Aphylles. Master's Thesis, Université d'Antananarivo, Antananarivo, Madagascar, 2018.

16. Cameron, K.M. Vanilloid orchids systematics and evolution. In Vanilla; Odoux, E., Grisoni, M., Eds.; Medicinal and Aromatic Plants-Industrial Profiles; CRC Press: Boca Raton, FL, USA, 2011; Volume 47, pp. 1-12. ISBN 978-1-4200-8338-5.

17. Griffiths, H.; Males, J. Succulent plants. Curr. Biol. 2017, 27, R890-R896. [CrossRef]

18. Gigant, R.L.; Bory, S.; Grisoni, M.; Besse, P. Biodiversity and evolution in the Vanilla genus. In The Dynamical Processes of Biodiversity: Case Studies of Evolution and Spatial Distribution; IntechOpen: Rijeka, Croatia, 2011; pp. 1-26. ISBN 978-953-307-772-7.

19. Gigant, R.L.; De Bruyn, A.; Church, B.; Humeau, L.; Gauvin-Bialecki, A.; Pailler, T.; Grisoni, M.; Besse, P. Active sexual reproduction but no sign of genetic diversity in range-edge populations of Vanilla roscheri Rchb. f. (Orchidaceae) in South Africa. Conserv. Genet. 2014, 15, 1403-1415. [CrossRef]

20. Soto Arenas, M.A.; Dressler, R.L. A revision of the Mexican and central American species of Vanilla Plumier ex Miller with a characterization of their ITS region of the nuclear ribosomal DNA. Lankesteriana 2010, 9, 285-354. [CrossRef]

21. Gigant, R.L.; De Bruyn, A.; M'sa, T.; Viscardi, G.; Gigord, L.; Gauvin-Bialecki, A.; Pailler, T.; Humeau, L.; Grisoni, M.; Besse, P. Combining pollination ecology and fine-scale spatial genetic structure analysis to unravel the reproductive strategy of an insular threatened orchid. S. Afr. J. Bot. 2016, 105, 25-35. [CrossRef]

22. Nielsen, L.R.; Siegismund, H.R. Interspecific differentiation and hybridization in Vanilla species (Orchidaceae). Heredity 1999, 83, 560-567. [CrossRef] [PubMed]

23. Rolfe, R.A. A revision of the genus Vanilla. Bot. J. Linn. Soc. 1896, 32, 439-478. [CrossRef]

24. Besse, P. Guidelines for the choice of sequences for molecular plant taxonomy. In Molecular Plant Taxonomy; Methods in Molecular Biology; Besse, P., Ed.; Humana Press: Totowa, NJ, USA, 2014; Volume 1115, pp. 39-51. ISBN 978-1-62703-766-2.

25. Azofeifa-Bolaños, J.B.; Gigant, R.L.; Nicolás-García, M.; Pignal, M.; Tavares-González, F.B.; Hágsater, E.; Salazar-Chávez, G.A.; Reyes-López, D.; Archila-Morales, F.L.; García-García, J.A.; et al. A new Vanilla species from Costa Rica closely related to V. planifolia (Orchidaceae). EJT 2017, 284, 1-26. [CrossRef]

26. Cameron, K.M. Recent advances in the systematic biology of Vanilla and related orchids (Orchidaceae: Subfamily Vanilloideae). In Proceedings of the Vanilla: First International Congress, Princeton, NJ, USA, 11-12 November 2003; Allured: Carol Stream, IL, USA, 2005; pp. 89-93.

27. Govaerts, R.; Bernet, P.; Kratochvil, K.; Gerlach, G.; Carr, G.; Alrich, P.; Pridgeon, A.M.; Pfahl, J.; Campacci, M.A.; Holland Baptista, D.; et al. World Checklist of Orchidaceae. Facilitated by the Royal Botanic Gardens, Kew. Available online: http://wcsp.science.kew.org/ (accessed on 17 July 2020).

28. IPNI International Plant Names Index. Available online: http://www.ipni.org (accessed on 17 July 2020).

29. MBG Tropicos: Connecting the World to Botanical Data since 1982. Available online: https://www.tropicos.org/ (accessed on 17 July 2020).

30. Pansarin, E.R.; Miranda, M.R. A new species of Vanilla (Orchidaceae: Vanilloideae) from Brazil. Phytotaxa 2016, 267, 84. [CrossRef]

31. Barberena, F.F.V.A.; Sousa, T.D.S.; Ambrosio-Moreira, B.D.S.; Roque, N. What are the species of phorophytes of Vanilla palmarum (Orchidaceae) in Brazil? An assessment of emblematic specificity with palm tree species. Rodriguésia 2019, 70, e02732017. [CrossRef]

32. Sambin, A.; Chiron, G.R. Deux Nouvelles Espèces de Vanilla (Orchidaceae) de Guyane Française. Richardiana 2015, XV, 306-316.

33. Porras-Alfaro, A.; Bayman, P. Mycorrhizal fungi of Vanilla: Diversity, specificity and effects on seed germination and plant growth. Mycologia 2007, 99, 510-525. [CrossRef]

34. Allorge-Boiteau, L. Les vanilles succulentes de Madagascar. Succulentes 2005, 2, 3-11.

35. Allorge-Boiteau, L. Une nouvelle espèce de vanille à Madagascar. Hommes Et Plantes 2013, 85, 4-5.

36. Soto Calvo, M.A.; Esperon, P.; Sauleda, R.P. A new species of Vanilla Miller is described for Cuba. New World Orchid Nomencl. Notes 2019, 56, 1-7. Available online: https://www.researchgate.net/profile/ Ruben_Sauleda/publication/341056775_A_New_Species_of_Vanilla_Miller_is_Described_for_Cuba/links/ 5eab47c5299bf18b958a7273/A-New-Species-of-Vanilla-Miller-is-Described-for-Cuba.pdf (accessed on 20 July 2020). 
37. Bory, S.; Brown, S.; Duval, M.-F.; Besse, P. Evolutionary processes and diversification in the genus Vanilla. In Vanilla; Odoux, E., Grisoni, M., Eds.; CRC Press: Boca Raton, FL, USA, 2010; pp. 15-29, ISBN 978-1-4200-8338-5.

38. Parizaca, A.D. Vanilla yanesha (Orchidaceae), a new species of the membranaceous-leaved group from the central rainforest of Peru. Willdenowia 2019, 49, 5. [CrossRef]

39. Flanagan, N.S.; Ospina-Calderón, N.H.; Agapito, L.T.G.; Mendoza, M.; Mateus, H.A. A new species of Vanilla (Orchidaceae) from the North West Amazon in Colombia. Phytotaxa 2018, 364, 250. [CrossRef]

40. Damian, A.; Mitidieri, N. Living in the clouds: A new high-elevation species of Vanilla (Orchidaceae, Vanilloideae) from Perú. Phytotaxa 2020, 451, 154-160. [CrossRef]

41. Cameron, K.M.; Chase, M.W. Phylogenetic relationships of Pogoniinae (Vanilloideae, Orchidaceae): An herbaceous example of the Eastern North America-Eastern Asia phytogeographic disjunction. J. Plant Res. 1999, 112, 317-329. [CrossRef]

42. Householder, E.; Janovec, J.; Mozambite, A.B.; Maceda, J.H.; Wells, J.; Valega, R. Diversity, natural history, and conservation of Vanilla (orchidaceae) in Amazonian wetlands of Madre De Dios, Peru. J. Bot. Res. Inst. Tex. 2010, 4, 227-243.

43. Nielsen, L.R. Natural hybridization between Vanilla claviculata (W.Wright) Sw. and V. barbellata Rchb.f. (Orchidaceae): Genetic, morphological, and pollination experimental data. Bot. J. Linn. Soc. 2000, 133, 285-302. [CrossRef]

44. Molineros Hurtado, F.; González Mina, R.T.; Flanagan, N.S.; Tupac Otero, J. Vanilla rivasii (orchidaceae), a new species from the Colombian pacific region. Lankesteriana 2014, 13. [CrossRef]

45. Tremblay, R.L.; Ackerman, J.D.; Zimmerman, J.K.; Calvo, R.N. Variation in sexual reproduction in orchids and its evolutionary consequences: A spasmodic journey to diversification. Biol. J. Linn. Soc. 2005, 84, 1-54. [CrossRef]

46. Gigant, R.L.; Rakotomanga, N.; Citadelle, G.; Silvestre, D.; Grisoni, M.; Besse, P. Microsatellite markers confirm self-pollination and autogamy in wild populations of Vanilla mexicana Mill. (syn. V. inodora) (Orchidaceae) in the island of Guadeloupe. In Microsatellite Markers; Abdurakhmonov, I., Ed.; IntechOpen: London, UK, 2016; pp. 73-93. ISBN 978-953-51-2797-0. [CrossRef]

47. Micheneau, C.; Johnson, S.D.; Fay, M.F. Orchid pollination: From Darwin to the present day. Bot. J. Linn. Soc. 2009, 161, 1-19. [CrossRef]

48. Peter, C.I.; Johnson, S.D. A pollinator shift explains floral divergence in an orchid species complex in South Africa. Ann. Bot. 2014, 113, 277-288. [CrossRef]

49. Bembé, B. Functional morphology in male euglossine bees and their ability to spray fragrances (Hymenoptera, Apidae, Euglossini). Apidologie 2004, 35, 283-291. [CrossRef]

50. Jersáková, J.; Johnson, S.D.; Kindlmann, P. Mechanisms and evolution of deceptive pollination in orchids. Biol. Rev. 2006, 81, 219-235. [CrossRef] [PubMed]

51. Tremblay, R.L. Trends in the pollination ecology of the Orchidaceae: Evolution and systematics. Can. J. Bot. 1992, 70, 642-650. [CrossRef]

52. Pansarin, E.R.; Pansarin, L.M. Floral biology of two Vanilloideae (Orchidaceae) primarily adapted to pollination by euglossine bees. Plant Biol. J. 2014. [CrossRef]

53. Petersson, L. Pollination Biology of the Endemic Orchid Vanilla bosseri in Madagascar. Master's Thesis, Biology Education Center, Disciplinary Domain of Science and Technology, Uppsala University, Uppsala, Sweden, 2015.

54. Ackerman, J.D.; Sabat, A.; Zimmerman, J.K. Seedling establishment in an epiphytic orchid: An experimental study of seed limitation. Oecologia 1996, 106, 192-198. [CrossRef]

55. Macedo, R.C.A. Biologia Reprodutiva e Propagacao Vegetativa de Vanilla chamissonis Klotzsch: Subsidios para Manejo Sustentado. Master's Thesis, Escola Superior de Agric Luiz de Queiroz, Piracicaba, Brazil, 2000.

56. Lubinsky, P.; Van Dam, M.; Van Dam, A. Pollination of Vanilla and evolution in the Orchidaceae. Lindleyana 2006, 75, 926-929.

57. Dressler, R.L. Phylogeny and Classification of the Orchid Family; Cambridge University Press: Cambridge, UK, 1993; ISBN 978-0-521-45058-4.

58. Chaipanich, V.V.; Wanachantararak, P.; Hasin, S. Floral morphology and Potential Pollinator of Vanilla siamensis Rolfe ex Downie (Orchidaceae: Vanilloideae) in Thailand. Thail. Nat. Hist. Mus. J. 2020, 14, 1-14. 
59. Divakaran, M.; Babu, K.N.; Ravindran, P.N.; Peter, K.V. Interspecific hybridization in Vanilla and molecular characterization of hybrids and selfed progenies using RAPD and AFLP markers. Sci. Hortic. 2006, 108, 414-422. [CrossRef]

60. Baack, E.; Melo, M.C.; Rieseberg, L.H.; Ortiz-Barrientos, D. The origins of reproductive isolation in plants. New Phytol. 2015, 207, 968-984. [CrossRef]

61. Schiestl, F.P.; Schlüter, P.M. Floral isolation, specialized pollination, and pollinator behavior in orchids. Annu. Rev. Entomol. 2009, 54, 425-446. [CrossRef]

62. Scopece, G.; Widmer, A.; Cozzolino, S. Evolution of postzygotic reproductive isolation in a guild of deceptive orchids. Am. Nat. 2008, 171, 315-326. [CrossRef] [PubMed]

63. Sun, M.; Schlüter, P.M.; Gross, K.; Schiestl, F.P. Floral isolation is the major reproductive barrier between a pair of rewarding orchid sister species. J. Evol. Biol. 2015, 28, 117-129. [CrossRef] [PubMed]

64. Minoo, D.; Jayakumar, V.N.; Veena, S.S.; Vimala, J.; Basha, A.; Saji, K.V.; Nirmal Babu, K.; Peter, K.V. Genetic variations and interrelationships in Vanilla planifolia and few related species as expressed by RAPD polymorphism. Genet. Resour. Crop. Evol. 2008, 55, 459-470. [CrossRef]

65. Lubinsky, P.; Cameron, K.M.; Molina, M.C.; Wong, M.; Lepers-Andrzejewski, S.; Gomez-Pompa, A.; Kim, S.-C. Neotropical roots of a Polynesian spice: The hybrid origin of Tahitian Vanilla, Vanilla tahitensis (Orchidaceae). Am. J. Bot. 2008, 95, 1040-1047. [CrossRef] [PubMed]

66. Barona-Colmenares, A.A. Two new records in Orchidaceae (Vanillinae) from southernmost Colombian Amazonia: Vanilla javieri, a new species, and Vanilla appendiculata. Phytotaxa 2018, 375, 261. [CrossRef]

67. Ennos, R.; French, G.; Hollingsworth, P. Conserving taxonomic complexity. Trends Ecol. Evol. 2005, 20, 164-168. [CrossRef] [PubMed]

68. Duval, M.-F.; Bory, S.; Andrzejewski, S.; Grisoni, M.; Besse, P.; Causse, S.; Charon, C.; Dron, M.; Odoux, E.; Wong, M. Diversité génétique des vanilliers dans leurs zones de dispersion secondaire. Les Actes du BRG 2006, 6, 181-196.

69. Bory, S.; Catrice, O.; Brown, S.; Leitch, I.J.; Gigant, R.L.; Chiroleu, F.; Grisoni, M.; Duval, M.-F.; Besse, P. Natural polyploidy in Vanilla planifolia (Orchidaceae). Genome 2008, 51, 816-826. [CrossRef]

70. Morales, F.A.; Menchaca, R.; Chiron, G.R. Notes on Mesoamerican orchids. II: Millenary use in the Q'eqchi communities of the lowlands, with a new Vanilla species. Richardiana 2019, 3, 100-108.

71. Watteyn, C.; Fremout, T.; Karremans, A.P.; Huarcaya, R.P.; Azofeifa Bolaños, J.B.; Reubens, B.; Muys, B. Vanilla distribution modeling for conservation and sustainable cultivation in a joint land sparing/sharing concept. Ecosphere 2020, 11, 1-18. [CrossRef]

72. Fouché, J.G.; Jouve, L. Vanilla planifolia: History, botany and culture in Reunion island. Agronomie 1999, 19, 689-703. [CrossRef]

73. Koyyappurath, S.; Conéjéro, G.; Dijoux, J.B.; Lapeyre-Montès, F.; Jade, K.; Chiroleu, F.; Gatineau, F.; Verdeil, J.L.; Besse, P.; Grisoni, M. Differential responses of Vanilla accessions to root rot and colonization by Fusarium oxysporum f. sp. radicis-vanillae. Front. Plant Sci. 2015, 6, 1125. [CrossRef] [PubMed]

74. Bond, M.O.; Aregullin, M.A.; Laux, M.T. Antimicrobial, cytotoxic and antiproliferative properties of native and invasive orchids in the Dominican ethnobotany. Pennscience 2014, 12, $23-28$.

75. Hernandez-Hernandez, J. Vanilla diseases. In Handbook of Vanilla Science and Technology; Havkin-Frenkel, D., Belanger, F.C., Eds.; Wiley-Blackwell: Chichester, UK, 2011; pp. 26-39, ISBN 978-1-4051-9325-2.

76. Kannan, M.; Senthil Kumar, T.; Rao, M. Utilization of plant resources for non-medicinal purposes by Malayali tribes of Kalrayan hills of Salem District, Tamil Nadu, India. Int. J. Herb. Med. 2016, 4, 47-58.

77. Balasubramanian, P.; Rajasekaran, A.; Prasad, S.N. Notes on the distribution and ethnobotany of some medicinal orchids in Nilgiri Biosphere Reserve. Zoos Print J. 2000, 15, 368. [CrossRef]

78. Raveloarison, M.; Jeannoda, V.H.; Ramarosandratana, A.V. Traditional uses of wild Vanilla species in Madagascar. In Proceedings of the XXI AETFAT Congress, Nairobi, Kenya, 15-19 May 2017.

79. Randrianarivony, T.N.; Ramarosandratana, A.V.; Andriamihajarivo, T.H.; Rakotoarivony, F.; Jeannoda, V.H.; Randrianasolo, A.; Bussmann, R.W. The most used medicinal plants by communities in Mahaboboka, Amboronabo, Mikoboka, Southwestern Madagascar. J. Ethnobiol. Ethnomed. 2017, 13, 19. [CrossRef]

80. Rakotoarivelo, N.H.; Randrianarivony, T.N.; Rakotoarivony, F.; Randrianasolo, A. "Mangidy": Malagasy folk beverages sold in Madagascar's marketplaces. Ethnobot. Res. Appl. 2019, 18, 1-14. [CrossRef] 
81. Randriamiharisoa, M.N.; Kuhlman, A.R.; Jeannoda, V.; Rabarison, H.; Rakotoarivelo, N.; Randrianarivony, T.; Raktoarivony, F.; Randrianasolo, A.; Bussmann, R.W. Medicinal plants sold in the markets of Antananarivo, Madagascar. J. Ethnobiol. Ethnomed. 2015, 11, 60. [CrossRef]

82. IUCN. The IUCN Red List of Threatened Species. Available online: https://www.iucnredlist.org (accessed on 17 September 2020).

83. Fraga, C.N.D.; Couto, D.R.; Pansarin, E.R. Two new species of Vanilla (Orchidaceae) in the Brazilian Atlantic Forest. Phytotaxa 2017, 296, 63. [CrossRef]

84. Pansarin, E.R. Vanilla dietschiana: An endangered species native to Brazil. Orchids 2010, 79, 106-109.

85. Pansarin, E.R. Taxonomic notes on Vanilleae (Orchidaceae: Vanilloideae): Vanilla dietschiana, a Rare South American Taxon Transferred from Dictyophyllaria. Selbyana 2010, 30, $203-207$.

86. Raffi, A.; Nordin, F.A.; Abdullah, N.A.P.; Go, R. Vanilla norashikiniana R. Go et A. Raffi sp. nov., a new orchid species from Peninsular Malaysia. Malay. Nat. J. 2017, 69, 273-276.

87. La Liste Rouge des Espèces Menacées en France: Flore Vasculaire de Mayotte. Available online: https:// uicn.fr/wp-content/uploads/2016/06/Dossier_presse_Liste_rouge_Flore_vasculaire_de_Mayotte (accessed on 28 August 2020).

88. Combrink, A.S.; Kyle, R. A Handbook on the Rare, Threatened and Endemic Species of the Greater St Lucia Wetland Park. A product of the Greater St Lucia Wetland Park-Rare, Threatened \& Endemic Species Project, Unpublished Internal Report. Available online: https:/www.globalnature.org/bausteine.net/f/6381/Rare\% 2CThreatenedandEndemicSpeciesReport_SouthAfrica.pdf?fd=2 (accessed on 29 August 2020).

89. Frankham, R.; Ballou, J.D.; Briscoe, D.A. Introduction to Conservation Genetics; Cambridge University Press: Cambridge, UK, 2010; ISBN 978-0-521-87847-0.

90. Flanagan, N.S.; Mosquera-Espinosa, A.T. An integrated strategy for the conservation and sustainable use of native Vanilla species in Colombia. Lankesteriana 2016, 16. [CrossRef]

91. Van der Niet, T.; Peakall, R.; Johnson, S.D. Pollinator-driven ecological speciation in plants: New evidence and future perspectives. Ann. Bot. 2014, 113, 199-212. [CrossRef]

92. Vences, M.; Wollenberg, K.C.; Vieites, D.R.; Lees, D.C. Madagascar as a model region of species diversification. Trends Ecol. Evol. 2009, 24, 456-465. [CrossRef]

93. Burgess, N.D.; Hales, J.D.; Underwood, E.; Dinerstein, E.; Olson, D.; Itoua, I.; Schipper, J.; Ricketts, T.; Newman, K. Terrestrial Ecoregions of Africa and Madagascar: A Conservation Assessment; Island Press: Washington, DC, USA, 2004; ISBN 978-1-55963-364-2.

94. Luke, W.R.Q. Rapid Assessment of Terrestrial Plant Diversity of Mnazi Bay Ruvuma Estuary Marine Park, Tanzania. Available online: https:/portals.iucn.org/library/sites/library/files/documents/2004-098.pdf (accessed on 29 August 2020).

95. Barley, A.J.; White, J.; Diesmos, A.C.; Brown, R.M. The challenge of species delimitation at the extremes: Diversification without morphological change in Philippine sun skinks. Evolution 2013, 67, 3556-3572. [CrossRef]

96. Gottlieb, L.D. Rethinking classic examples of recent speciation in plants. New Phytol. 2003, 161, 71-82. [CrossRef]

97. Shaffer, H.B.; Thomson, R.C. Delimiting species in recent radiations. Syst. Biol. 2007, 56, 896-906. [CrossRef]

98. Rundell, R.J.; Price, T.D. Adaptive radiation, nonadaptive radiation, ecological speciation and nonecological speciation. Trends Ecol. Evol. 2009, 24, 394-399. [CrossRef]

99. Grant, P.R.; Grant, B.R.; Petren, K. Hybridization in the recent past. Am. Nat. 2005, 166, 56-67. [CrossRef]

100. Verma, P.C.; Chakrabarty, D.; Jena, S.N.; Mishra, D.K.; Singh, P.K.; Sawant, S.V.; Tuli, R. The extent of genetic diversity among Vanilla species: Comparative results for RAPD and ISSR. Ind. Crop. Prod. 2009, 29, 581-589. [CrossRef]

101. Cameron, K.M. Vanilla Orchids: Natural History and Cultivation; Timber Press: Portland, OR, USA, 2011; ISBN 978-0-88192-989-8.

102. Warren, B.H.; Bermingham, E.; Bowie, R.C.K.; Prys-Jones, R.P.; Thébaud, C. Molecular phylogeography reveals island colonization history and diversification of western Indian Ocean sunbirds (Nectarinia: Nectariniidae). Mol. Phylogenetics Evol. 2003, 29, 67-85. [CrossRef]

103. Warren, B.H.; Bermingham, E.; Prys-Jones, R.P.; Thebaud, C. Tracking island colonization history and phenotypic shifts in Indian Ocean bulbuls (Hypsipetes: Pycnonotidae). Biol. J. Linn. Soc. 2005, 85, 271-287. [CrossRef] 
104. Kainulainen, K.; Razafimandimbison, S.G.; Wikström, N.; Bremer, B. Island hopping, long-distance dispersal and species radiation in the Western Indian Ocean: Historical biogeography of the Coffeeae alliance (Rubiaceae). J. Biogeogr. 2017, 44, 1966-1979. [CrossRef]

105. Jaros, U.; Fischer, G.A.; Pailler, T.; Comes, H.P. Spatial patterns of AFLP diversity in Bulbophyllum occultum (Orchidaceae) indicate long-term refugial isolation in Madagascar and long-distance colonization effects in La Réunion. Heredity 2016, 116, 434-446. [CrossRef]

106. Micheneau, C.; Carlsward, B.S.; Fay, M.F.; Bytebier, B.; Pailler, T.; Chase, M.W. Phylogenetics and biogeography of Mascarene angraecoid orchids (Vandeae, Orchidaceae). Mol. Phylogenetics Evol. 2008, 46, 908-922. [CrossRef]

107. Andriananjamanantsoa, H.N. Systématique évolutive et biogéographie de Angraecum (Orchidaceae, Angraeinae) à Madagascar. Ph.D. Thesis, Université de Montréal, Montreal, QC, Canada, 2015.

108. Warren, B.H.; Simberloff, D.; Ricklefs, R.E.; Aguilée, R.; Condamine, F.L.; Gravel, D.; Morlon, H.; Mouquet, N.; Rosindell, J.; Casquet, J.; et al. Islands as model systems in ecology and evolution: Prospects fifty years after MacArthur-Wilson. Ecol. Lett. 2015, 18, 200-217. [CrossRef]

109. Darwin, C.M.A. On the Origin of Species by Means of Natural Selection, or the Preservation of Favoured Races in the Struggle for Life, 2nd ed.; John Murray: London, UK, 1859; pp. 10-394.

110. Myers, N.; Mittermeier, R.A.; Mittermeier, C.G.; da Fonseca, G.A.B.; Kent, J. Biodiversity hotspots for conservation priorities. Nature 2000, 403, 853-858. [CrossRef]

111. Blair, M.E.; Sterling, E.J.; Dusch, M.; Raxworthy, C.J.; Pearson, R.G. Ecological divergence and speciation between lemur (Eulemur) sister species in Madagascar. J. Evol. Biol. 2013, 26, 1790-1801. [CrossRef]

112. Yoder, A.D.; Heckman, K.L. Mouse lemur phylogeography revises a model of ecogeographic constraint in Madagascar. In Primate Biogeography; Developments in Primatology: Progress and Prospects; Springer: Boston, MA, USA, 2006; pp. 255-268. ISBN 978-0-387-29871-9.

113. Panitsa, M.; Koutsias, N.; Tsiripidis, I.; Zotos, A.; Dimopoulos, P. Species-based versus habitat-based evaluation for conservation status assessment of habitat types in the East Aegean islands (Greece). J. Nat. Conserv. 2011, 19, 269-275. [CrossRef]

114. Bickford, D.; Lohman, D.J.; Sodhi, N.S.; Ng, P.K.L.; Meier, R.; Winker, K.; Ingram, K.K.; Das, I. Cryptic species as a window on diversity and conservation. Trends Ecol. Evol. 2007, 22, 148-155. [CrossRef] [PubMed]

115. Bortolus, A. Error cascades in the biological sciences: The unwanted consequences of using bad taxonomy in ecology. Ambio J. Hum. Environ. 2008, 37, 114-118. [CrossRef]

116. Duminil, J.; Kenfack, D.; Viscosi, V.; Grumiau, L.; Hardy, O.J. Testing species delimitation in sympatric species complexes: The case of an African tropical tree, Carapa spp. (Meliaceae). Mol. Phylogenetics Evol. 2012, 62, 275-285. [CrossRef] [PubMed]

117. Rouhan, G.; Gaudeul, M. Plant taxonomy: A historical perspective, current challenges, and perspectives. In Molecular Plant Taxonomy; Methods in Molecular Biology; Besse, P., Ed.; Humana Press: Totowa, NJ, USA, 2014; Volume 1115, pp. 1-37, ISBN 978-1-62703-766-2.

118. Besse, P.; Da Silva, D.; Grisoni, M. Plant DNA barcoding principles and limits: A case study in the genus Vanilla. In Molecular Plant Taxonomy Methods and Protocols; Besse, P., Ed.; Springer: New York, NY, USA, 2020; in press.

119. Razafinarivo, N.J.; Guyot, R.; Davis, A.P.; Couturon, E.; Hamon, S.; Crouzillat, D.; Rigoreau, M.; Dubreuil-Tranchant, C.; Poncet, V.; De Kochko, A.; et al. Genetic structure and diversity of coffee (Coffea) across Africa and the Indian Ocean islands revealed using microsatellites. Ann. Bot. 2013, 111, 229-248. [CrossRef] [PubMed]

120. Stebbins, G.L. Variation and evolution in plants: Progress during the past twenty years. In Essays in Evolution and Genetics in Honor of Theodosius Dobzhansky: A Supplement to Evolutionary Biology; Hecht, M.K., Steere, W.C., Eds.; Springer: Boston, MA, USA, 1970; pp. 173-208, ISBN 978-1-4615-9585-4.

121. Surveswaran, S.; Gowda, V.; Sun, M. Using an integrated approach to identify cryptic species, divergence patterns and hybrid species in Asian ladies' tresses orchids (Spiranthes, Orchidaceae). Mol. Phylogenetics Evol. 2018, 124, 106-121. [CrossRef]

122. Shafer, A.B.A.; Wolf, J.B.W. Widespread evidence for incipient ecological speciation: A meta-analysis of isolation-by-ecology. Ecol. Lett. 2013, 16, 940-950. [CrossRef] 
123. Ramírez-Barrera, S.M.; Velasco, J.A.; Orozco-Téllez, T.M.; Vázquez-López, A.M.; Hernández-Baños, B.E. What drives genetic and phenotypic divergence in the Red-crowned Ant tanager (Habia rubica, Aves: Cardinalidae), a polytypic species? Ecol. Evol. 2019, 9, 12339-12352. [CrossRef]

124. Wang, I.J.; Bradburd, G.S. Isolation by environment. Mol. Ecol. 2014, 23, 5649-5662. [CrossRef]

Publisher's Note: MDPI stays neutral with regard to jurisdictional claims in published maps and institutional affiliations.

(C) 2020 by the authors. Licensee MDPI, Basel, Switzerland. This article is an open access article distributed under the terms and conditions of the Creative Commons Attribution (CC BY) license (http://creativecommons.org/licenses/by/4.0/). 